\title{
OSMANLI DEFIN MERASIMLERINDE OTAĞ KURMA GELENEĞI
}

\author{
TURGAY YAZAR*
}

Son yıllarda çeşitlenerek artan Osmanlı araştırmaları, şimdiye kadar ele alınmamış pek çok konuyu gündeme getirmeye başlamıştır. Osmanlı dönemi defin merasimleri de son yllarda gündeme gelen konulardan biridir. Defin merasimleri semiyotik bir sistem içerisinde ele alınabilecek dini, örfi ve siyasi yönleri olan birçok uygulamayı bünyesinde toplamaktadır. Bu uygulamalardan biri de sultanların naaşları veya mezarları üzerine otağ kurulmasıdır ${ }^{1}$.

Osmanlı tarih kaynaklarında sultan naaşı üzerine otağ kurulduğuna dair ilk bilgi, I. Murad'ın 1398 yılındaki Kosova Savaşı'nda şehit edilmesiyle ilgili anlatılarda geçer.

•Yrd. Doç. Dr., Cumhuriyet Universitesi, Edebiyat Fakültesi, Sanat Tarihi Bölümü, Sivas/TURKiYE, turgayyazar@yahoo.com

Mezar veya naaş üzerine otağ kurulması Osmanlı sultanlan için düzenlenen defin merasimlerinin önemli bir parçası olsa da bu konuyu tek başına ele alan bir araşurma tespit edilememiştir. Osmanlı defin merasimlerini ele alan genel çalışmalann bir kısmında ise konu gündeme getirilmiş olmakla birlikte üzerinde yeterince durulmamış ve kapsamlı bir değerlendirme yapılmamışur. Bk. Nicolas Vatin-Gilles Veinstein, "Les obsèques des sultans ottomans de Mehmed II à Ahmed I “(1481-1616)", Les Ottomans et la mort: permanences et mutations, ed: Gilles Veinstein, E. J. Brill, Leiden, New York, Köln, 1996, s. 207-244; Le Sérail ébranlé Essai sur les morts, dépositions et avènements des sultans ottomans (XIV-XIX'siècle), Fayard, Paris 2003, s. 427-430; "II. Mehmed'den I. Ahmed'e Osmanh Padişahlanın Cenaze Törenleri (1481-1616)", Osmanllar ve Olium, yay. haz. Gilles Veinstein, çev. Ela Gültekin, İletişim Yayınlan, İstanbul 2007, s. 253-298; Zeynep Tanm Ertuğ, XVI. Yüzynl Osmanh Deuleti'nde Cülûs ve Cenaze Törenleri, Kültür Bakanlı̆ı Yaynlan, Ankara 1999, s. 89-137; Edhem Eldem, Istanbul'da Ölüm Osmanh İslam Külttïründe Ólüm ve Ritiielleri, Osmanh Bankası Arşiv ve Araşturma Merkezi, İstanbul 2005, s. 80-113. Yukanda belirtilen çalışmalann yanı sıra II. Mahmud ve sonrasındaki sultanlanı ölüm ve defin merasimleri ile ilgili bir yüksek lisans tezini de burada belirtmek gerekir. Bk. Servet Yanatma, "The Deaths and Funeral Ceremonies of Ottoman Sultans (From Sultan Mahmud II to Sultan Vahideddin)", Boğaziçi Universitesi, Sosyal Bilimler Lisansüstü Araşturmalan Enstitüsü, Yayımlanmamı̧̧ Yüksek Lisans Tezi, İstanbul 2006.

Türklerin İslam öncesi defin geleneklerini ele alan bazı araştırmalarda da konuya değinilmiştir. Bk. Nejat Diyarbekirli, Türklerde Mezar Yapısı ve Defin Merasimleri”, Türk Kültürü Araştırmalan, Prof. Dr. Muharrem Ergin'e Armağan, 28/1-2(1992), s. 53-62; Yaşar Çoruhlu, "Kurgan ve Çadır (Yurt)'dan Kümbet ve Türbeye Geçiş", Geģmişten Günümüze Mezarlık Külttürü ve Insan Hayatına Etkileri Sempozyumu, 18-20 Araltk 1998 , AKSM-Istanbul, Istanbul 1999, s. 47-63; Turgay Yazar, "Çadır-Bark-Türbe", Geçmişten Günümüze Mezarlık Kültürü ve İnsan Hayatna Etkileri Sempozyumu, 18-20 Aralık 1998, AKSM-Istanbul, Istanbul 1999, s. 418-431. 
Anlatılara göre, savaş meydanında şehit olan sultanın naaşı üzerine hemen bir otağ kurulmuştur. Bu olayı nakleden Enveri² (öl. 1465 sonrası) "Şah üzere anda ģadır kurdılar", Âşık Paşazade ${ }^{3}$ (öl. 1484 sonrası), "hemen padişahın üzerine şadır kurdular" ve Mehmed

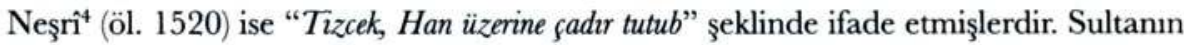
naaşııın tahnit edilerek iç organlarının gömüldüğü bu otağ daha sonra kaldırılmıs ve yerine sultanın makam türbesi inşa edilmiştir ${ }^{5}$.

Mezarı üzerine otağ kurulduğuna dair bilgimiz olan ilk sultan ise I. Selim'dir. Celâl-zâde'nin ${ }^{6}$ (öl. 1567) verdiği bilgiye göre 1520'de Edirne'ye giderken Çorlu'da ölen sultanın naaşı İstanbul'a getirilmiş, Edirne Kapısı'nda arabadan çıkarlarak tabuta konulmuş, cenaze namazı Fatih Camii'nde kılındıktan sonra inşa ettirmekte olduğu caminin mihrabı önüne defnedilerek üzerine otağ kurulmuştur.

\begin{abstract}
"Vakt-i zuhrda idi merhûm cennet-mekân ve firdevs-âşiyânın na'ş-1 rahmetnakşlan dahi gelüb, hazret-i Hudâvendigâr-ı'âlem-sitân süvar olub, Edirne kapusı mukâbelesinde vâki' olan püşte üzerinde istikbâl eylediler. Ol mahalde cism-i şeriffleri 'arabadan çıkarlub, taht-1 tabuta konulub, erbâb-1 tevhîd-i temcîd ve müezzinân-1 sa'âdet-nüvid âvâze-i rahmet-endâzelerini ayyukâ çıkarub, 'âmme-i mü'minin ve gürûh-1 muvahhidîn du'â-yı hayr ile fầtiha-i fahiya kır'at iderlerdi. Câmi'-i sa'âdet-nişân Hazret-i Sultân Muhammed Hân-1 cennet âşiyândan namâz-1 şeriffleri kllnnub, derûn-i Kostantnnyye'de olan cibâl-i rahmet-iştimâlden Mirzâ Sarâyı dimekle ma'rûf bir câ-yı bülend ve makâm-1 sâmî ve ercümend var idi, ki cümle emkineden fâyik ve a'lâ, ve mecmû'-1 mesâkîn-i müslimînden bülend-ü bâlâdır, ol makâm-ı mübârek ve sa'âdet-mend türbe-i 'ulyâlan içün ihzâr olunub, zât-1 rahmet-makrûnları anda medfûn olub, üzerlerine utâk-1 rahmet-menzil kurlub, tilâvet-i Kur'ân-1 'azîm içün hâfizlar ve hârisler ta'yîn olunub, makâm-1 behişt-berîn zuhur eyledi."
\end{abstract}

I. Selim'in defin merasimi Solak-zâde (öl. 1657) ${ }^{7}$ tarafindan da benzer şekilde anlatilmıştır:

"Vakt-i zuhurda merhum cennet mekân ve halled-aşiyân hazretlerinin naaş-1 rahmetleri dahi gelüb hazret-i Hüdâvendigâr esb-süvar olup Edirne kapusu

${ }^{2}$ Fatih Devri Kaynaklarndan Düstürnàme-i Enveri, Osmanle Tarihi Kisme (1299-1456), haz. Necdet Oztürk, Kitabevi Yaymlan, İstanbul 2003, s. 33/350.

${ }^{3}$ Âşık Paşazade, Osmanoğullan'nnn Tarihi, haz. Kemal Yavuz-M. A. Yekta Saraç, K Kitaphı̆ğ, İstanbul 2003, s. 125.

' Mehmed Neşri, Kìtab-ı Cihan-numá Negyn Tanihi, c. I, yay. F.R. Unat-M. A. Köymen, Türk Tarih Kurumu Yayınlan, Ankara 1987, s. 305. 295-296

${ }^{5}$ Bk. Semavi Eyice, "Hudâvendigar Meşhedi", Türkiye Diyanet Vakłi İlam Ansiklopedisi, 18(1998), s.

${ }^{6}$ Celâl-zâde Mustafa, Selim-nâme, haz. Ahmet Uğur-Mustafa Çuhadar, Kültür Bakanlı̆ı̆ Yayınlan, İstanbul 1990, s. 221-222, 453.

' Solak-zâde Mehmed Hemdemî Çelebî, Solak-zade Tarihi, Mahmud Bey Matbaası, İstanbul 1297 (1880), s. 423-424. 
mukabelesinde vâki' olan pişe üzerinde istikbâl idüp ol mahalde cism-i şerîflerin arabadan çıkardılar ve tabuta koyub ashab-1 tevhid ve temcid ve müezzinân-1 saadet nüvid-i avâze-i rahmet endâzeleri ayyûka çıkarub cedleri Sultan Mehmed Han Gâzî hazretlerinin câmi'-i şeriffine alub geldiler. Ve namazın anda kıldılar ve derûn-1 şehirde olan cibâl ve rahmet-iştimâlden Mirzâ Sarâyı dimekle ma'rûf bir âli câ-yı bülend makâm-1 sâmî aramgâhi ve kendülere neşimen-i ebedi olmak içün ol makam-1 mübarek türbe-i ulyalan içün ihzâr olunup zat-1 rahmet makrûnlan anda defn olundu. Ve üzerlerine otak-1 âlîye kurulup tilâveti Kur'ân-1 azîmü'ş-şan içün hâfizlar ta'yin olunub kırk gün muhâfazadan sonra, hazret-i padişah peder-i saadet-intizâmlanmın merkadi civannda hukuk-1 ebeveti eda üzere bir âli câmi'-i cennet makam ve imaret-i güzin-i hayrr-encam yapturdılar."

Mezan üzerine otağ kurulduğunu bildiğimiz ikinci sultan I. Süleyman'dır. I. Süleyman 1566 yılında Zigetvar'da ölmüş, İstanbul'a getirilen naaşı Süleymaniye Camii haziresindeki otağ içerisinde hazırlanan mezarına defnedilmiştir. Saray Şehnamecisi Seyyid Lokman Aşurî tarafindan yazılarak saray nakkaşhanesinde resimlenen ve I. Süleyman'ın son yıllarını anlatan 1579 tarihli Zafernâme'nin (Tarih-i Sultan Süleyman) 115 b sayfasında sultanın naaşının Süleymaniye Camii haziresine getirilmesi ve mezarının hazırlanması resmedilmiştir $(\operatorname{Resim} 1)^{8}$.

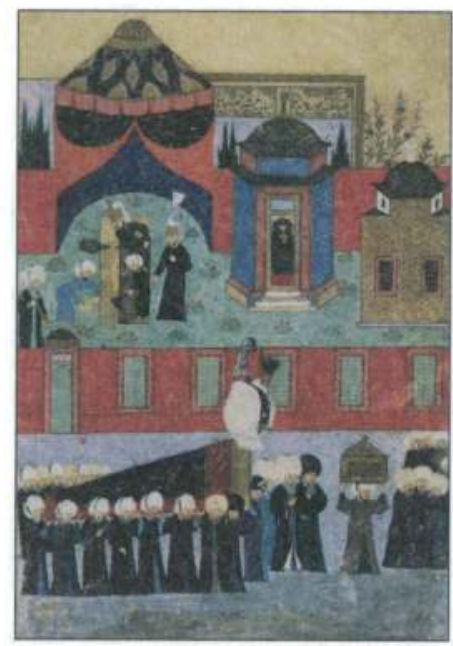

Resim 1. Zafernâme, I. Süleyman'ın naaşının Süleymaniye Camii haziresine getirilmesi ve mezarınun hazırlanması.

Resmin ön kısmında I. Süleyman'ın kırmızı desenli siyah bir Kâbe örtüsü yayılan, baş tarafina sorguçlu büyük bir sarık yerleştirilmiş olan tabutu matem elbise-

${ }^{8}$ Dublin Chester Beatty Kütüphanesi MS 413. Kullanılan resim Serpil Bağcr-Filiz Çağman-Günsel Renda ve Zeren Tanınd, Osmanl Resim Sanatı, ed. Serpil Bağcı, Kültür ve Turizm Bakanlı̆ı Yayınlan, İstanbul 2006, s. 120'den alınmıştır. 
leri giyinmiş ulema tarafından taşınmaktadır. Tabutun arkasında matem elbiseleri içinde, yanında ise şemle giyinmiş figürler bulunmaktadır. Cenaze alayının önünde Kanuni'nin birlikte gömülmeyi vasiyet ettiği söylenen çekmecesini taşıyan bir görevli vardır. Resmin sağında matem elbiseleri içinde ellerini başlarının iki yanına koyarak sultanın ölümüne feryat eden ağlayıcılar yer almaktadır. Resmin üst tarafinda bir duvarla çevrelenmiş Süleymaniye Camii'nin haziresi görülmektedir. Hazirede Hürrem Sultan Türbesi'nin hemen yanına kurulmuş bir otağ içinde dört görevli tarafindan sultanın mezan hazırlanmaktadır. Resmin solunda mezarın hazırlanmasına nezaret eden ve elinde zira (arşın) tutan kişinin Mimar Sinan olduğu sanılmaktadır.

Mezarı üzerine otağ kurulduğunu bildiğimiz üçüncü sultan II. Selim'dir. 1574 y1lında Topkapı Sarayı'nda vefat eden II. Selim'in naaşı vezirler tarafindan kaldırılmış, namazı kılındıktan sonra Ayasofya Camii avlusunda hazırlanan mezarına defnedilerek üzerine otağ kurulmuştur. Sultanın ölümünden sonra sarayda boğdurulan beş şehzadenin naaşları da cenaze namazları kılınarak babalarının mezarının bulunduğu otağ içerisinde defnedilmiştir. Sultanın ve şehzadelerin naaşlarının otağ içerisindeki mezarlara defnedilmesi Selânikî (öl. 1600) ${ }^{9}$ tarafindan aşağıdaki gibi anlatılmıştır:

"Namaz ve du'â-i Fâtiha'dan sonra sa'âdetlü Pâdişâh harem-i şerife teveccüh idüp, na'ş-1 şerîfi vüzerâ hazretleri kaldırup ve girîv ü feryâd ve âh u nâle vü zârî ile mele-i a' lâda olanlan inledüp Sarây-1 Âmire'den taşra çıkduğı gibi âmme-i âlem bir vechile zârî vü efgān eyledilerki cenâzeyi bi'z-zarûre turgurdılar âhir yap yap ma 'bed-i kadîm olan Ayasofya Câmi'-i şerîfinün haremi garb cânibinde olan sâha-i şerîfede merkad-i münevverleri kazılan mahalle getürilüp, kabr-i şerîf hâzır olınca otak kurılup, ulemâ ve sulehâ ve meşâyih etrâfinı alup, tesbîh u tehlîle meşgül oldılar. Rahmetu'llâhi aleyh."

\section{"Şehzâdelerün cenâzeleri çıkduğıdur.}

Ba'dehû içerüden kapucılar kethüdâsı gelüp vüzerâ ve erkân-1 devleti tekrâr Bab-1 Hümâyûn'dan içerü alup, gidüp beş nefer şehzâdelerün tabutların kaldırup; pâdişâh-ı merhumûn namazı kılındugı yerde namazlanı kılınup kezâlik taşra, halk-1 âleme çıkardılar. Allâh ta'âlâ -celle zikruhû- ol gün İstanbul halkınun feryâd u figānın, melâ'ike-i arş-1 azîme dinledüp, zî-rûh olanlara hikmet ü ibretin müşâhede itdürdi. Bu hâlet üzre ma'sûmların tabutların âh u nâleler ve zikr ü tesbîhler ile merhûm ve mağfurun-lehün na'ş-1 şerîfi olduğı çadıra getürdiler. İki neferin bir tarafa ve üç neferin berü tarafa koyup ol gice ulemâ ve sulehâ tilâvet-i Kur'an-1 azîm eylediler."

\section{Şehzâdelerün defn olunduklandur.}

Rûz-i penç-şenbih ramazân-1 şerîfün dokuzuncı günidur, altı aded merâkıd-1 şerîfe ile hâzırlanup ve beş nefer şehzâdelerün kabirleri mükemmel olunup, merhûm ve mağfurun-lehün ayağı ucuna defn olindılar." 
Bu tarihlerde Avusturya elçilik heyetinin vaizi olarak İstanbul'da bulunan Stephan Gerlach ${ }^{10}$ Ayasofya Camii haziresindeki otağı ve içerisindeki sandukaları görmüştür. Gerlach'ın anlatısına göre sultanın sırma ipliklerle dokunmuş örtülerle kaphı sandukasının üzerine sırma işlemeli bir kumaş yayılmıştır. Sandukanın başucunda tüylerle süslü bir sarkk vardır. Ayakucuna öldürülen şehzadelerin küȩük sandukaları dizilmiştir. Üzerlerine örtüler serilen sandukaların üstüne şehzadelerin giysileri ve altun kuşakları yerleştirilmiştir. Her bir sandukanın başucunda güzel tüylerle bezenmiş birer sarık ile siyah ve beyaz sırma ipliklerle dokunmuş birer mendil bulunmaktadır. Sandukaların etrafı iri taneli boncuk dizisi ile çevrilidir. Otağın içerisi cam vazolara konulan çiçekler ve güllerle süslenmiş, sultanın sandukasının önüne iki büyük mum yerleştirilmiştir. Sandukaların etrafinda oturan din adamları ölenler için dua ve ilahiler okumakta, gelip geçen ahali ise otağın dışında yere çömelerek dua etmektedir.

Selânikî ve Gerlach'ın verdiği bilgiler aynı dönemden günümüze ulaşan bir resimle de doğrulanır. Freshfield Albümü olarak bilinen 1574 tarihli albümde II. Selim ve boğdurulan beş şehzadesinin sandukalarının konulduğu otağı gösteren bir resim bulunmaktadır (Resim 2)".

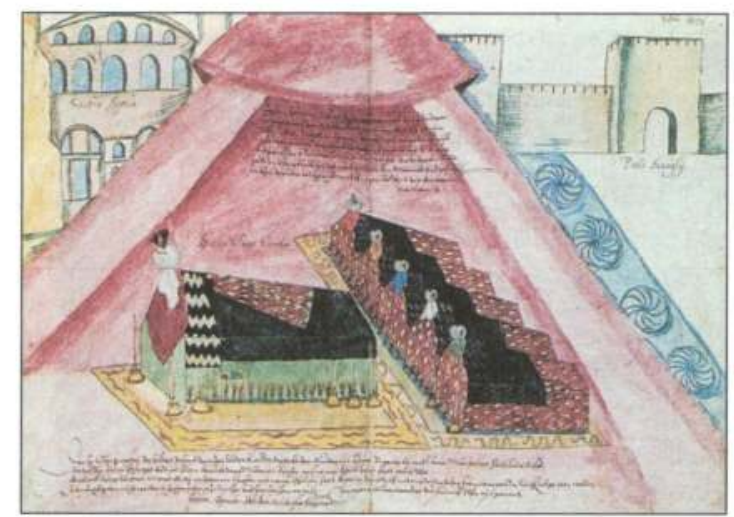

Resim 2. Freshfield Albümü, Ayasofya Camii avlusundaki II. Selim ve şehzadelerinin mezarlan üzerine kurulan otağ.

Resimde II. Selim'in sandukası önde, şehzadelerin sandukaları ise II. Selim'in sandukasının ayakucuna dizilmiştir. Baş taraflarında sarıkları bulunan sandukalar yere serilen halılar üzerine yerleştirilmiştir. Sandukaların üzerine Kâbe örtüleri ve kıymetli kumaşlar yayılmıs, etraflarına ise kandiller konulmuştur.

${ }^{10}$ Stephan Gerlach, Türkìye Günlüğü 1573-1576, c. I, ed. Kemal Beydilli, çev. Türkis Noyan, Kitap Yaynevi, Istanbul 2007, s. 169.

"Cambirdge Universitesi, Tirinity Koleji Kütüphanesi, MS. 0.17.2, y. 21. Kullanılan resim Diyarbekirli, a.ge., res. 18'den alınmıştır. 
Mezan üzerine otağ kurulduğunu bildiğimiz dördüncü sultan III. Murad'dır. 1595 yılında Topkapı Sarayı'nda vefat eden sultanın naaşı burada yıkanıp kefenlendikten sonra namazı kılınmış, Ayasofya Camii haziresinde hazırlanan mezarına defnedilerek üzerine otağ kurulmuştur. III. Murad'ın defin merasimi ve mezan üzerine kurulan otağ Hasan Bey-zâde (öl. 1636) ${ }^{12}$ tarafindan aşağıdaki gibi anlatılmıştır:

"[Pâdişâh-1 hulâfet-penâh, kalkup, içerü gidüp, vâlid-i mâcidinün na'ş-1 rahmetnakşı levâzımmı ber-vech-i cemîl, itmâm u tekmil itdürdükten sonra,] ba 'îd-i asrda, merhûm-1 merkūmun cenâzesi dahi çıkup, Sarây-1 hümâyûn fezâsında, namâzı müft̂ imâmeti ile kılınup, [kendüler, Harem-i muhterem'e gidup,] Ayasofya kurbında, ta'yîn eyledükleri gülzârda, [hafr u] ihzâr olınan mezânnda, defn ihtiyâr olındı...

[Cenâze-i mezbûreyi kaldurup, gülzâr-1 mezârına iletdiler ve serî́an, defn eylediler ve üstine otak-1 gerdûn-kıyâm kurup, hâzır olan fukarâ'-i enâmı it'âm ve hatemât-1 kelâm-1 Melik-i Allâm itmekle, rûh-1 pür-fütûhlarını vâsıl-1 nesîm-i dârü's-selâm eylediler] ve ol evân-1 kuyâmet-nişânda, Sarây-1 hümâyûn'da [Şâh-1 âlîş̧ânun birâderleri olan] ontokuz nefer şehzâde, bilâ-cürm ü istihkāk, şühedâ zümresine ilhâk olınup; lâkin na'ş-1 rahmet-nakşlan ol gün, çıkarılmağa mecâl olmayup, gurûb, karîb olmağla, zamân, kat teng olup, techîzlerinde direng iktizâ eylemeğin, irtesi günde, ale's-sabâh, çıkarılup,

Ki ân zamân nebüved der reh-i du'â perde (953)

ol şühedâ'-i ma'sûmîn-i mazlûmîn] namâzlan fezâ'-i Dîvan'da Müfti'l-müslimîn imâmeti ile edâ olınup, atalan Pâdişâh-1 merküm-1 merhûmun ayağı ucunda, defn olındılar. [Ol günde, fukarâ vü eytâma it'âm-1 ta'âm ve bezl-i sadakāt u in'âm ve rûh-1 pür-fütûhlan içün, kurrâ vü huffầ-1 enâm, hatemât-1 kelâm-1 Mecîd-i Allâm idüp, mevâlî-i izâm ile du'âya kxyâm itdiler.]"

III. Murad'ın defin merasimi ve mezanı hakkında Hasan Bey-zâde'nin yanı sıra bu yllarda Venedik Cumhuriyeti İstanbul Büyükelçisi olan Marco Venier'in Venedik devlet başkanı ve senatosuna gönderdiği bir rapordan da bilgi alınmaktadır ${ }^{13}$. Büyükelçinin gönderdiği rapora göre III. Murad'ın naaşı Ayasofya Camii haziresine kurulan büyük ve görkemli bir askeri çadırın içerisinde hazırlanan mezarına defnedilmiştir. Cenaze merasiminden sonra sarayda boğdurulan ondokuz şehzadenin tabutlan da ertesi gün defnedilmek üzere çadıra getirilmiş ve babalarının mezarının çevresine yerleştirilmiştir.

Mezan üzerine otağ kurulduğunu bildiğimiz beşinci sultan III. Mehmed'dir. Hasan Bey-zâde ${ }^{14}$ ve Solak-zâde'nin ${ }^{15}$ verdiği bilgilere göre 1603 yılında Topkapı Sarayı'nda vefat eden sultanın naaşı burada yıkanıp kefenlendikten sonra namazı kılınmıs, Ayasofya Camii avlusunda II. Selim Türbesi'nin yanında hazırlanan mezarına defnedilerek me-

${ }^{12}$ Hasan Bey-zâde Ahmed Paşa, Hasan Bey-zade Tarihi, c. III, haz. Şevki Nezihi Aykut, Türk Tarih Kurumu Yaymlan, Ankara 2004, s. 430-431, 433-434.

${ }^{13}$ H. G. Rosedale, Queen Elizabeth and the Levant Company A Diplomatic and Literary Episode of the Establishment of our Trade with Turkey, Oxford University Pres, London 1904, s. 39.

${ }^{14}$ Hasan Bey-zâde, a.ge., s. 805-807.

${ }^{15}$ Solak-zâde, a.ge., s. 684. 
zanı üzerine otağ kurulmuştur. Hasan Bey-zâde III. Mehmed'in defin merasimiyle ilgili bilgi verirken mezan üzerine otağ kurulduğunu şöyle ifade etmektedir:

"Emr-i techîz ü tekfin, itmâma irüşüp, [mukarrebân u havâşî olan ağayân-1 tavâşî,] tâbût-1 rahmet-men'ût [-1 Sultânı götürüp, Bâb-1 sa'âdet-me'âb'dan taşra çıkarduklarında,] cesedleri görindüği gibi, [vüzerầ -i saff-ârâ,] seğürdüp omuzlanna alup, meydân-1 Divân'da, nasb eyledükleri kürsi-i refi'-i feleknişâna vaz' eylediler. [Pâdişâh-1 İslâm dahi, ol makāmda, hazır olup,] Müftî-i asra namâzın kıldurdılar. Pâdişâh-1 cedìd, içerüye gidüp, cenâzeyi ekābir, götürüp, Sultân Selîm-i halìm-türbesi bâğçesinde, hafr u ihzâr eyledikleri mezâr-1 pür envârına iletüp, defn eylediler. [Mustafa Paşa-hânkāhı şeyhi Şeyh Hasan, levâzım-1 telkîni edâ vü karîn eyledükten sonra, kabir] üzerine otak-1 âlî-nitâk kurilup, huffâz u kurrâ, tilâvet-i Kur'ân-1 kerîm'e meşgul oldılar ve rûh- 1 pürfütûhı içun, ta âm tabh olınup, fukarâ-i enâm, it âm olındılar."

III. Mehmed'in defin merasimi Solak-zâde tarafindan da anlatılmıştur.

Vüzera ve ulema şemle getirub başlarına sardılar ve sairleri birer siyah çember bağlayarak müfti-i zaman ve erkân-1 bâb-1 saade yanında dizilub durdular. Merhum Sultan Mehmed Hanın naaş-1 rahmet-nakşı çıkmasına mütevakkıf oldular. Emr-i techiz ve tekfin itmama erişüb tabut-1 cesedleri göründüğü gibi vüzera seğirdüb ve omuzlanna alub meydan-ı divanda iskemle üzerine koyub müfti-i asır Mustafa Efendiye namazın kıldırdılar. Padişah-1 cedid gerü içeriye gidüp cenazeyi götürüb Sultan Selim-i Halìm türbesi bahçesinde hafr ve ihzar eyledikleri mezar-1 pür-enverlerine defn eylediler. Ve üzerine otak-1 âlì nitâk kurulub huffàz ve kurrâ tilâvete meşgül oldular. Ve ruh-1 pür futuhu içün taamlar tabh olunub fukara-yı enàm it'am olundular".

Mezarı üzerine otağ kurulduğunu tespit ettiğimiz son sultan II. Mahmud'dur. 1839 yılında kız kardeşi Esma Sultan'ın Çamlıca'daki köşkünde vefat eden II. Mahmud'un naaşı Topkapı Sarayı'na getirilmiş, burada yıkanıp kefenlendikten sonra cenaze namazı kılınmış, büyük bir kalabalık eşliğinde defin yeri olarak belirlediği Esma Sultan'ın Divanyolu'ndaki sarayının bahçesine defnedilerek ${ }^{16}$ mezarı üzerine otağ kurulmuştur. II. Mahmud'un mezan üzerine kurulan otağı sultanın mezarını ziyaret eden Alman subay Helmuth von Moltke görmüştür. Moltke ${ }^{17}$ II. Mahmud'un mezan ve üzerindeki otağ hakkında aşağıdaki bilgiyi vermektedir:

"Marmara deniziyle liman arasında ve Nuruosmaniye camii yakınındaki bir sırtta, yerküresinin başka hiçbir yerinde böyle zengin bir tarzda bir araya gelmemiş kasabalar, denizler, dağlar, adalar, saraylar ve donanmalann genel panoraması seyredilir; bir zamanlar Sultan Mahmut, orada gömülmek istediğini söylemiş. Tabutunu işte buraya getirmişler; üzerine bir çadır kurulmuş, türbe de şimdi bu çadınn üzerinde kubbelenecek, çünkü müteveffa hükümdarnn kemiklerinin bir kere daha rahatsız edilmemesi lazım. Huzur ve sükûn içinde yatsınlar."

${ }^{16}$ II. Mahmud'un cenaze merasimi için bk. Ahmet Lütfi Efendi, Vałkanüvis Ahmed Lütfi Tarihi, c. 6-7-8, haz. Yücel Demirel, Tarih Vakfi-Yapı Kredi Yayınlan, İstanbul 1999, s. 1006-1007; Ali Akyıldız, "Sultan II. Mahmud’un Hastalı̆̆ ve Olümu," Türk Kültürü Incelemeleri Dergisi, 4(2001), s. 68-70.

${ }^{17}$ Helmuth von Moltke, Moltke'nin Tiankiye Mektuplan, çev. Hayrullah Ors, Remzi Kitabevi, Istanbul 1969, s. 277. 
Osmanlı tarihleri ve seyahatnamelerde sultan mezarlarının yanı sıra şehzade naaşlanı ve şehit mezarları üzerine de otağ kurulduğunu gösteren bilgiler vardır. Şehzade naaşı üzerine otağ kurulduğunu dair bilgi Şehzade Mustafa'nın öldürülmesiyle ilgili anlatılarda geçmektedir. Anlatulara göre Şehzade Mustafa 1553 yılındaki İran seferi sırasında Konya Ereğli'si civarındaki Aktepe adlı bir menzilde konaklayan babası I. Süleyman'ın elini öpmek üzere ordugâha gelmiş, kendisini karşllayan bir saray çavuşu tarafindan otağ-1 hümâyûna kadar götürülmüş, içeri girer girmez cellatlar tarafindan kementle boğulmuştur ${ }^{18}$.

Şehzade Mustafa'nın öldürülmesi Seyid Lokman tarafindan yazılan ve I. Süleyman'ın hünerlerinin konu edildiği 1589 tarihli Hünernâme'nin ${ }^{19}$ ikinci cildinde hem anlatılmış hem de resimlenmiştir. Hünernâme'ye göre, öldürülen şehzade şehit naaşlarında olduğu gibi giyindiği beyaz kaftanı kefen kabul edilerek kapı önüne çıkarılıp uzatılmış ve üzerine otağ kurulmuştur (Resim3).

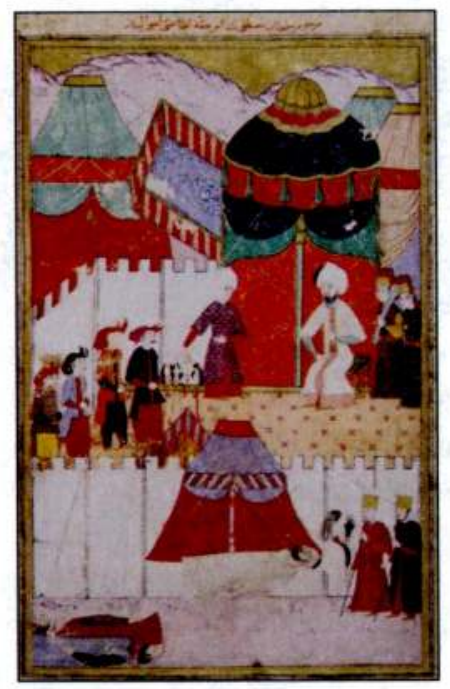

Resim 3. Hünername, Şehzade Mustafa'ın boğularak öldürülmesi ve teşhiri.

Úst kısmına "Merhum Sultan Mustafa'nun emr-i Hakk'a itaati ahvalidir" yazll olan resmin sağ üst köşesinde perdeden yapılan bir çit (zukak) içindeki otağında beyaz bir kaftan giyinmiş olarak oturan Sultan Süleyman, karşısında duran bir görevlinin işaret ettiği art arda dizilmiş dört cellâda bakmaktadır. Sultanın hemen arkasında has odalı iki ağa bulunmaktadır. Padişahın otağını ordugâhtan ayıran çitin dışında ise boğdurulan şehzade ve naaşı üzerine kurulan otağ resmedilmiştir. Şehzadenin üzerinde beyaz

${ }^{18}$ Bk. Şerafettin Turan, Kamuni Sultan Süleyman Dönemi Taht Kangalan, Bilgi Yaymlan, Ankara 1997, s. 37-39.
${ }^{19}$ Seyid Lokman, Hünernâme, cild-i sâní, Topkapı Sarayı Müzesi Kütüphanesi, H. 1524, v. 168b, 169a-b. 
bir kaftan bulunmaktadır. Başı açık olan şehzadenin sorguçlu sarığı yanı başındadır. Otağın hemen yanında ellerinde sopalarıyla iki görevli şehzadenin naaşına nezaret etmektedir. Az ileride ise şehzadenin başları vurdurulan iki adamı, Şahbey ve Rıdvan Bey gelişigüzel bir şekilde yatmaktadır (Resim 3).

Şehit mezarlan üzerine otağ kurulduğuna dair bilgi ise Evliya Çelebi'nin (öl. 1684?) Seyahatnâme'si ile Silâhdar'ın (öl. 1723) Nusretnâme'sinde verilmiştir. Evliya Çelebi'nin belirttiğine göre ${ }^{20}$; 1663 yılındaki Uyvar seferi sırasında Estergon'da meydana gelen Ciğerdelen Muhasarası'nda şehit olan askerlerin naaşları toplanarak bir mezara defnedilmiş, üzerine otağ kurulup üç gün üç gece Kur'an okutulmuştur.

\begin{abstract}
"Bu kıssa-i pür-hisseden Sadra'zam hissedâr ve haberdâr olunca hemân ale'ssabâh cemî'i şuhedâlanımızın na'şe-i münevverelerin sahrâ-yı Ciğerdelen'de buldurup cümle Üstürgon tarafina getirdüp serâperde-i Berhayâ kurbunda Süleymân Hân depesi zeylinde bir hafr-i azîm kazdırup cümle bin altmış aded şehîdânın henüz bir gün bir geceden berü kanlan revân olarak Ordu Monlası Ûnsî Efendi cenâze-i şehîdân-ı gâ'ibân namâzına muktedâ olup iki kerre yüz bin aded guzât-1 muvahhidîn şehîdân namâzına bir kümeden hâzır olup \{namâz-1 şehîdân kılınup \} cümle şühedâyı biri biri üzre balık istifi gibi yığup defn etdiler."

Ve bu şehîd üzre haymeler kurulup cümle Ústürgon ulemâlan üç gün üç gece tilâvet-i Kur'an etmeğe me'mur olup Sadria'zamdan ulemâlara ihsân[u] in'âmlar oldu"
\end{abstract}

Silâhdar'in Nusretnâme'de ${ }^{21}$ verdiği bilgiye göre ise 1695 yılında Logoß̧ (Lugoş/ Lugos) Kalesi'nin fethi sırasında şehit olan Şahin Mehmed Paşa, Arnavud Mehmed Paşa ve Siroto Hüseyin Bey'in naaşları Sultan II. Mustafa'nın (1695-1703) kendi otağı içerisinde hazırlattığı kabirlere defnedilmiştir.

"Şevketlû Padişah, askerlerin maneviyatın yükseltmek ve onlan savaşa teşvik için Vezir Şahin Mehmed Paşa, Arnavud Mehmed Paşa ve Siroto Hüseyin Bey'in cenazelerini Otağ-1 hümâyuna getirerek, yüzlerini açtunp her birine ayn ayrı duâlarda bulunarak, şehidlerin ruhlarını şâd ettikten sonra, Âdil Köşkü önünde İçhalkı ile birlikte cenaze namazlarını kıldı. Şahin Mehmed Paşa ile Hüsrev Bey fikıh kitaplanında yazılı olduğu şekilde, kanlı gömlekleri ile otağ içinde hazırlanan kabirlerine defnedildiler. Mahmud Paşa ise ölmeden önce dünya kelamı ettiği için cenazesi usulüyle yıkandıktan sonra gömüldü. Bu üç şehid yan yana toprağa konulduktan sonra mezarlan toprak ile yulaf örtülerek belirsiz bir hale getirildi. Padişahımız bunlar hakkında "Gerçi düşman ordusunu perişan ettim amma, ne çare ki Mahmudumla Şahinimden ayrıldım» diyerek duyduğu üzüntüyü belirtmişti.”

${ }^{20}$ Evliya Celebi b. Derviş Mehemmed Zilli, Evliya Çelebi Seyahatnamesi Topkapı Saray Kütüphanesi Revan 1457 Numarah Yazmann Transkripsiyonu-Dizini, haz. Seyit Ali Kahraman-Yücel Dağlı, Yapı Kredi Yayınlan, İstanbul 2002, s. 187.

${ }^{2 !}$ Silâhdar Findıklıı Mehmed Ağa, Nusretnâme, c. I, sad. İsmet Parmaksızoğlu, İstanbul 1962, s. 95. 
Yukarıda sunulan örnekler Osmanh defin merasimlerinde sultanlar, şehzadeler ve şehit mezarlan üzerine otağ kurulmasının yaygın bir uygulama olduğunu göstermektedir. Bu uygulamanın doğru olarak anlaşılması için konunun hem Türklerin İslam öncesi defin gelenekleri, hem de İslami defin kuralları ve uygulamaları açısından değerlendirilmesi gerekir.

İslam öncesi Türk defin merasimlerinde ${ }^{22}$ naaşın çadıra konulduğuna dair ilk bilgi Bat Hunları hakanı Attila'nı 453 yılında yapılan cenaze merasimiyle ilgili anlatularda geçmektedir. Got tarihçisi Jordanes'in ${ }^{23}$ nakline göre defin merasimi sırasında Attila'nın naaşı ordugâhının ortasına kurulan ipek bir çadırda ${ }^{24}$ tabuta konulmuştur. Hun seçkinleri atları ile çadırın çevresinde dolaşırken yası yöneten yaşılıar tarafindan Attila'nın hayatta iken yaptığı işler anlatılmış ve ağıtlar söylenmiştir. Yasa katılan erkekler saçlarını kesmişler ve yüzlerini çizerek derin yaralar açmışlardır.

Batı Hunlarında 5. yüzylda tespit edilen bu geleneğin Asya'da yaşayan diğer Hun boylan veya topluluklarında da olması kuvvetle muhtemeldir ${ }^{25}$. Çin yıllıklarında yer alan Göktürk defin merasimleriyle ilgili anlatılar bu ihtimali doğrulamaktadır. Yıllıklarda verilen bilgiye göre Göktürkler ölülerini merasim için kurulan bir çadırın içine koymakta, ailesi ve akrabaları ölüye kurban sunmakta, at ile çadırın çevresini dolaşarak yüzlerini bıçakla kesmekte, böylece kan ve yaşın birlikte aktığı bu merasim yedi defa tekrarlanmaktadir ${ }^{26}$.

Elimizdeki bilgilere göre bu gelenek sadece Türklerle de sınırlı değildir. Pencikent'teki II Numaralı Tapınak'ın güney duvarındaki 7-8. yüzyllara tarihlenen Sogd dönemine ait bir duvar resminde yas merasimi tasvir edilmiştir. Resimde naaşın bir çadır içerisine konulduğu görülmektedir. Çadırın içerisinde ve çevresinde saçlarını ve yüzlerini kesip feryat ederek yas tutan figürler vardır (Resim 4$)^{27}$.

${ }^{22}$ Türklerin İslam öncesi defin merasimleri için bk. Abdülkadir Inan, Tarihte ve Bugün Şamanizm Materyaller ve Araştarmalar, Türk Tarih Kurumu Yaynlan, Ankara 1954, s. 176-200; Jean-Paul Roux, Altay Tïrklerinde Olïm, çev. Aykut Kazancıgil, Kabalc Yaynevi, İstanbul 1999, s. 238-293; Edward Tryjarski, Tiurkler ve Olìm, çev. Hafize Er, Pinhan Yaynlan, İstanbul 2012, s. 92-278.

${ }^{25}$ Jordanes, Romana et Getica. Monumenta Germaniae Historica: Auctores Antiquissimi, ed. Theodor Mommsen, Berlin 1882, s. 124-125.

${ }^{24}$ Bu çadınn ölenin kendi çadınmı yoksa naaş için kurulan ayn bir çadır mı olduğu tartışmalı olmakla birlikte ölü için kurulan ayn bir çadır olduğu kanaati daha yaygındır. Bk Roux, a.ge, s. 240; Tryjarski, a.ge, s. 188.

${ }^{25}$ Hun dönemi defin merasimleri için bk. Fuat Köprülü, Edebiyat Araştrrmalan, Türk Tarih Kurumu Yayınlan, Ankara 1986, s. 91-92; İsmail Görkem, "Türk Dünyasında Yas Törenleri ve Ağttlar", Tiük Diunyast Araş九urmalan, 77(1992), s. 158-160.

${ }^{26}$ Göktürk defin merasimleri için bk. İnan, a.ge., s. 177-178; Köprülü, a.ge., s. 88-89; Ahmet Taşağll, Göktiurkler, Türk Tarih Kurumu Yaynnlan, Ankara 1995, s. 98.

${ }^{27}$ Guitty Azarpay, Sogdian Painting The Pictorial Epic in Oriental Art, University of California Pres London 1981 , s. 127. 


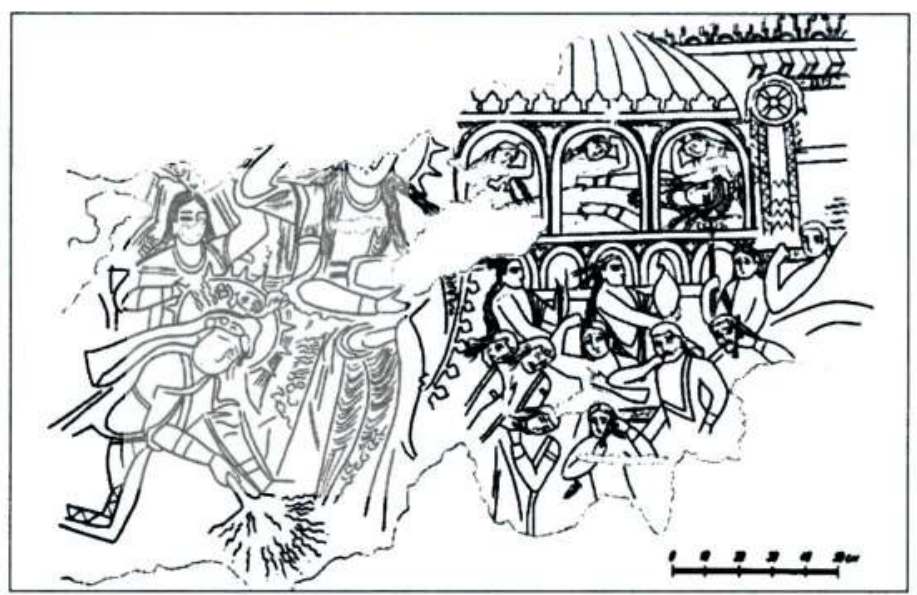

Resim 4. Pencikent II. Tapınak'taki ölü çadırı tasviri

Benzer bir geleneğin Moğollarda da varlığı bilinmektedir. Gizli Tarih'e göre Cengiz Han öldürttüğü Teb Tenggeri'nin naaşı üzerine çadır kurdurmuştur ${ }^{28}$.

“...Çinggis-hahan, Teb-tenggeri’nin bel kemiği kırılmış vaziyette bir köşede, arabaların yanında yatmakta olduğunu görünce üzerine boz bir çadır kurdurdu ve: Buradan gideceğiz!,, diye emir verdi. Bunun üzerine burasını terk ederek başka yere göç ettiler.

Teb'in üzerine kurulmuş olan çadırnn penceresi (bacası) kapatılmıs, kapısı örtülmüş ve etrafina nöbetçiler konmuştu. Böyle olduğu halde, üçüncü gün şafak sökerken çadının penceresi açıldı ve teb'in (vucudu da) kendiliğinden yükselerek kayboldu...".

Anlaşıldığı kadarıyla başta Türkler olmak üzere Asya'da yaşayan pek çok toplumda ölü çadırı kurulması defin merasimlerinin önemli bir parçasıdır. Türklerin İslam öncesi defin uygulamalan hakkında bilgi veren kaynaklarda ölü çadırı kurulmasının nedenleri belirtilmese de bazı çıkarımlarda bulunmak mümkündür. Çadır bozkır halkları tarafindan kutsal bir mesken olarak algılanmış ${ }^{29}$ bu nedenle de her türlü ayin ve merasim çadırda veya çevresinde gerçekleştirilmiştir ${ }^{30}$. Ölü çadırı sembolik değerinin yanı sıra defin için gerekli hazırlıkların yapıldığı bir mekân olarak da önem taşımak-

${ }^{28}$ Mangho-un Niuça Tobça'an (Yüan-Ch'ao Pi-shi), Moğollann Gizli Tarihi, çev. Ahmet Temir, Türk Tarih Kurumu Yaymlan, Ankara 1995, s. 167.

${ }^{29}$ Fuzuli Bayat, Türk Mitolojik Sistemi 1 (Ontolojik ve Epistemolojik Bağlamda Türk Mitolojisi), Otüken Neşriyat, Istanbul 2007, s. 43-44.

${ }^{30}$ Günümüz Kazak ve Kırgızlannda yurda yapılan sembolik göndermeler bu konunun önemini ortaya koyacak niteliktedir. Bk. Hélène Perin, "Kazaklarda ve Kırgızlarda Kara Ui Yurdu ve Yas Tutma (Çă̆daş Etnografya Verilerine Göre)", Osmanlılar ve Ölüm, yay. haz. Gilles Veinstein, çev. Ela Gültekin, İletişim Yaymları, Istanbul 2007, s. 75-92. 
tadır. Hun ve Göktürk defin merasimlerine ait anlatılara göre ölü çadırı içinde tahnit, kefenleme ve tabuta yerleştirme gibi işlemler yapılarak naaş defin için hazırlanmakta ${ }^{3 !}$ çevresinde ise ağıtlar söylenmesi, saçların kesilmesi, yüzün çizilmesi ve kurban sunulması gibi yas adetleri gerçekleştirilmektedir ${ }^{32}$. Bu nedenlerle bozkır halklan için ölü çadırı hem sembolik hem de işlevsel bir mesken niteliğine sahiptir.

Konuya İslami defin kuralları ve uygulamaları açısından bakıldığında ise ilk olarak İslam dünyasında defin kuralları ve mezar yapılarının çok tartışılan konulardan biri olduğunu belirtmek gerekir. Kur'ân'da açık ve kesin bir hüküm olmadığı için defin kuralları ve mezarların yapısı hakkında farklı görüşler ileri sürülmüştür ${ }^{33}$. Ancak genel kabullere göre kabirlerin kireç ve benzeri malzemeler kullanılarak yapılması, yükseltilmesi, üzerine kubbeli bina yapılması ile taşına övücü ve kaderden şikâyet edici sözler yazılmasının yasak olduğunda ittifak edilmiş, hatta bazı ulema bunların haram olduğu sonucuna varmıştır ${ }^{34}$.

Mezar üzerine çadır kurulmasında da benzer bir durum söz konusudur. Buhari tarafindan nakledilen bir hadise göre, Hz. Muhammed, Hz. Ebû Bekr'in oğlu Abdurrahman'ın (öl. 673) mezarı üzerine kurulu bulunan çadırı kaldırtmıştır 'İbn Umer (R) Ebû Bekr'in oğlu Abdurrahmân'ın kabri üzerinde bir çadır gördü de: Ey oğul, bu çadın sök, fü̈nü ölüyü kabrinde ancak kendi ameli gölgeler, dedi’35.

Ahmed bin Hanbel'in Müsned'inde yer alan bir rivayete göre Ebû Hüreyre ${ }^{36}$ (öl. 678) kabrinin üstüne çadır kurulmamasını vasiyet etmiştir. Ahmed bin Hanbel'in de ${ }^{37}$ (öl. 855) mezarlar üzerine yünden dokunan bir tür çadır olan "fustat" kurulmasına karşı çıktığı ve oğlu İbrahim'e kendi mezanı üzerine çadır kurulmamasını söylediği rivayet edilmektedir ${ }^{38}$.

Bazı hadis ve rivayetlerde mezarlar üzerine çadır kurulması men edilse de, ulema arasındaki farklı görüşler nedeniyle bu kısıtlamalara her zaman uyulmamıştır. İmam

3! Tryjarski, a.ge., 181-204.

${ }^{32}$ Görkem, a.g.m., s. 158-166; Tryjarski, a.ge., s 147-166.

${ }^{33}$ Youssef Raghep, "Islam Hukukuna Göre Mezann Yapıs1", Cimetières et Traditions Funéraires dans le Monde Islamique Islam Diüyasznda Mezarlkklar ve Defin Gelenekleri, c. I, ed. Jean-Louis Bacqué-Aksel Tibet, Türk Tarih Kurumu Yayınlan, Ankara 1996, s. 17-23.

${ }^{34}$ Hayreddin Karaman, "Olüm, Olü, Defin ve Merasimler", Cimetières et Traditions Funéraires dans le Monde Islamique İslàm Dünyastnda Mezarlkklar ve Defin Gelenekleri, c. I, ed. Jean-Louis Bacqué-Aksel Tibet, Türk Tarih Kurumu Yaymlan: Ankara 1996, s. 9.

${ }^{35}$ Sahîh-i Buhari ve Tercemesi, c. 3, çev. Mehmed Sofuoğlu, Otüken Yayınlan, İstanbul 1987, s. 1283.

${ }^{36}$ Sahabe ve birçok hadisin ravisi olan Ebû Hüreyre için bk. M. Yaşar Kandemir, "Ebû Hüreyre", Türkiye Diyanet Vakfi Islam Ansiklopedisi, 10(1994), s. 160-167.

${ }^{37}$ Ahmed bin Hanbel, mezheb imam, muhaddis ve fakihtir. Bk. M. Yaşar Kandemir, "Ahmed b. Hanbel", Türkiye Diyanet Vakfi İslam Ansiklopedisi, 2(1989), s. 75-80.

3a Zeynü'd-dîn Ahmed b. Ahmed b. Abdi'l-Lâtifi'z-Zebîhî, Sahîh-i Buhari Muhtasan Tecrid-i Sarih Tercemesi ve Şerhi, c. 4, çev. Kâmil Miras, Diyanet İşleri Başkanlı̆̆ Yayınları, Ankara 1980, s. 452, 480. 
Şafî̀ (öl. 820), el-Üm'de ${ }^{39}$ Mekke'de mezarlıklardaki kubbelerin yıktırıldığını gördüğünü, ancak ulemadan hiç kimsenin bunları yasaklamadığını ifade etmiş, Ali el-Kârî de ${ }^{40}$ (öl. 1014), tanınmış şeyh ve ulema kabirlerine insanların ziyaret ve dinlenmesi için kubbe kurulmasına selefin izin verdiğini belirtmiştir ${ }^{41}$.

Mezar üzerine çadır kurulup kurulmayacağı konusunda başlangıçta bir tartışma olsa da bu uygulamanın sonradan yasaklandığı anlaşılmaktadır. Örneğin Abdullah İbn Abbas'ın $^{42}$ (öl. 688) Ta'if'deki mescidinde bulunan kabri üzerine çadır (fustat) kurulmuş, fakat bu çadır daha sonra kaldırılmıştır. Buhari'den nakledildiğine göre Hazret-i Alî’nin torunu Hasan İbn-i Hasen'in (öl. 669) mezan üzerine eşi Fatma Binti-i Hüseyn, Ümmü'l-Mü'minîn Zeyneb Bint-i Cahş'ın (öl. 641) mezan üzerine ise Hz. Ömer (öl. 644) tarafindan bir kubbe ${ }^{43}$ kurdurulmuş, ancak daha sonra bu kubbeler kaldırılmıştır ${ }^{44}$.

Mezar üzerine çadır kurulması Memluk sultanlarının defin merasimlerinde de saptanmaktadır. Memlûklu tarihçisi İbni Tagrıberdi’nin (öl. 1466) verdiği bilgiye göre Sultan Melik Zahir Berkuk'un (öl. 1399) mezarı üzerine çadır kurulmuştur ${ }^{45}$.

"Emirler ve kadılar vasiyetine uygun cenaze namazını kıldıktan sonra nâşını omuzlarında taşıyarak yol kenannda bir yere, çevresi duvarlarla çevrilmemiş bir mezara Cuma namazından önce defnettiler. Ondan önce hiçbir Mısır hükümdan gündüz gömülmemiş ve mezan üzerine bir çadır kurulmamıştır. Cenazesi defnedildikten sonra o çadırda günlerce Kur'an okunmuş, kalabalık halk kitlelerine yemekler verilmiş, birkaç gün boyunca devlet erkanı mezan ziyarete gelmiş ve halk üzüntüye olmuştur."

İslam dünyasında yukarıda bahsedilen rivayetler ve tarihçilerin verdiği bilgilerin yanı sıra mezarlar üzerine çadır kurulduğunu gösteren görsel kaynaklar da bulunmaktadır. Bunlardan biri 7. yüzyılda yaşamış bir Arap şairi olan Urvâ ibn Hizam'ın hikâyesine dayanan ve 11. yüzyılda Ayyuki tarafindan Farsça yazılarak Gazneli Sultan Mahmud'a sunulan Varka ve Gülşah isimli bir aşk hikâyesidir. Bu hikâyenin 12. yüzylın sonu veya 13. yüzyılın başlarına tarihlenen bir nüshasında bulunan Varka'yı aldatmak için yapılan Gülşah'ın sahte mezanı ve sözde yas tutan anne ve babası ile Şam hüküm-

${ }^{39}$ İmam Şafî̀nin fikıh konusundaki görüşlerini yanıtsan ve mezhebin ana kaynağı olan eserdir. Bk. Bilal Aybakan, "Şâfî", Türkiye Diyanet Vakfi Islam Ansiklopedisi, 38(2010), s. 230.

40 Ali el-Kâri, tanımış bir Hanefi fakihi, muhaddis, müfessir ve kıraat âlimidir. Bk. Ahmet Ozel, "Ali el-Kâri", Türkiye Diyanet Vakfi İslam Ansiklopedisi, 2(1989), s. 403-405.

${ }^{41}$ Zeynü'd-din Ahmed, a.ge., s. 481.

${ }^{42} \mathrm{~Hz}$ Muhammed'in amcasının oğludur. 70 yaşlannda Taif'te ölmüş ve orada defnedilmiştir. Bk. İsmail L. Çakan-Muhammed Eroğlu, "Abdullah b. Abbas", Türkiye Diyanet Vakfi İslam Ansiklopedisi, 1(1988), s. 76-78.

${ }^{43}$ Metinlerde geçen kubbe lafzının kâgir kubbe olmadığı, İbn Esir'in (öl. 1233) kabirier üzerine kurulan kubbeleri "çadıdan ma'mul kubbe" olarak tanımlamasından anlaşlmaktadır. Bk. Zeynü'd-dîn Ahmed, a.ge., s. 481-482.

${ }^{44}$ Zeynü'd-dîn Ahmed, a.ge., s. 480; Abbas Danesvari, Medieval Tomb Towers of Iran an Iconographical Study, Mazada Publishers, Lexington, 1986, s. 10-11; Sofuoğlu, a.ge., s. 1252.

4 İ İni Tagnberdi, En-Nucûm'uz-Zâhire (Panldayan Yildızlar), çev. D. Ahsen Batur, Selenge Yaynlan, Istanbul 2013, s. 313. 
darının Varka ile Gülşah'ın mezarını ziyaret etmesini gösteren iki resimde de mezar üzerine çadır kurulmuştur (Resim 5-6) ${ }^{46}$.

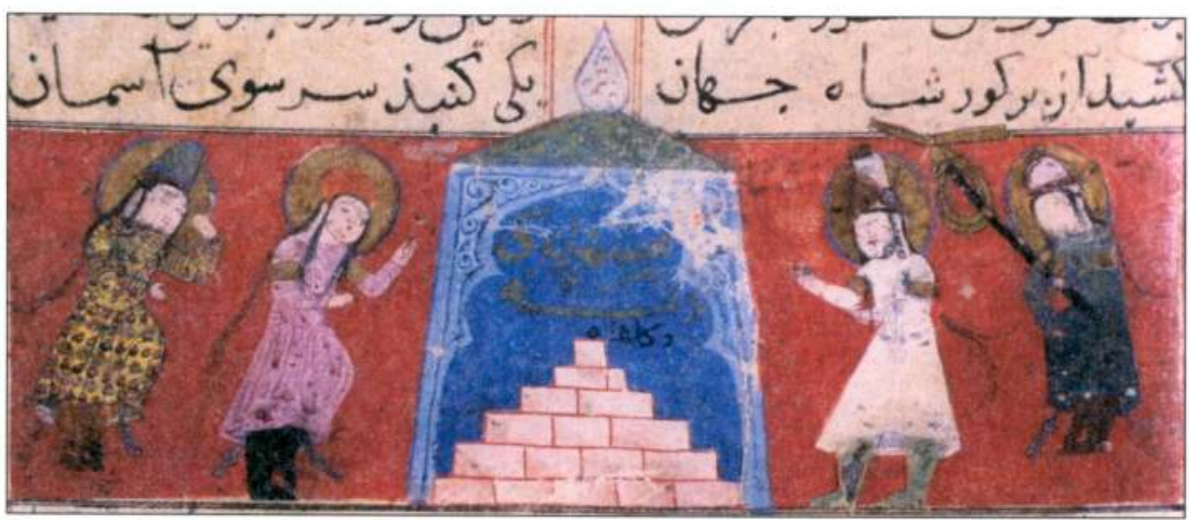

Resim 5. Varka ve Gülşah, Gülşah'ın sahte mezarı ve sözde yas tutan anne ve babası.

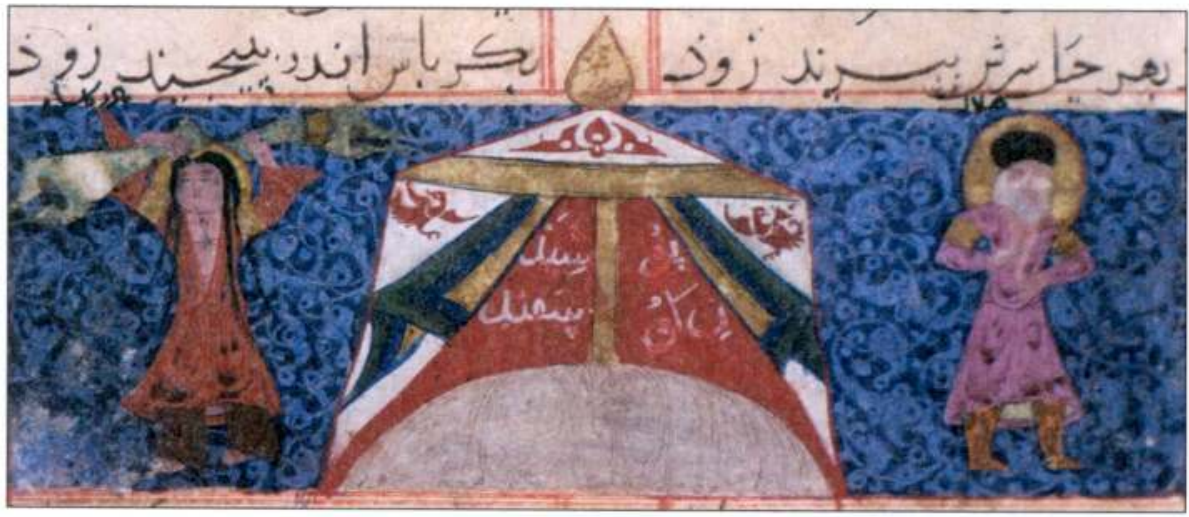

Resim 6. Varka ve Gülşah; Şam hükümdarının Varka ile Gülşah'ın mezarını ziyareti.

Mezar üzerine çadır kurulduğunu gösteren bir tasvir de Timurlu döneminde hazırlanmış 1444 tarihli Nizami'nin Hamse'sinde bulunmaktadır ${ }^{47}$. Yazmanın İskender'in tabutu başında ağıt yakılmasını gösteren resminde naaş çadır içerisinde hazırlanan bir mezara konulmuştur. Çadını çevresinde elbiselerinin yakalarını yırtıp feryat ederek yas gösterileri yapan figürler vardır $(\operatorname{Resim} 7)^{48}$.

${ }^{46}$ Topkapı Sarayı Müzesi Kütüphanesi, Hazine 481, v. 46a, 58b.

47 Topkapı Sarayı Müzesi Kütüphanesi, H. 870, y. 304a. Bk. Serpil Bağcı, "İslam Toplumlannda Matemi Simgeleyen Renkler: Mavi, Mor ve Siyah", Cimetières et traditions funéraires dans le monde islamique Islâm Diünyastnda Mezartkklar ve Defin Geleneklen, c. II, ed. Jean-Louis Bacqué-Aksel Tibet, Türk Tarih Kurumu, Ankara 1996, s. 164.

${ }^{48}$ Kullanılan resim $B a g ̆ c$, "Mavi, Mor ve Siyah", a.g.e, resim 4'ten alınmıştur. 


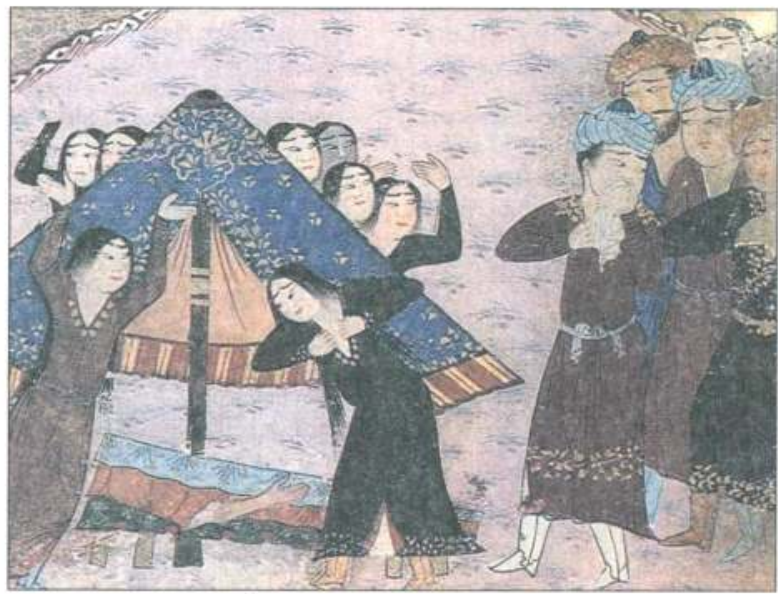

Resim 7. Hamse, Iskender'in tabutu başında ağıt yakılması.

Mezar üzerine çadır kurulmasını İslami ikonografi açısından da değerlendirmek gerekir. İkonografik olarak mezar üzerine düşürülen gölgenin sembolik bir cennet imgesi oluşturduğu, bunun da mezar üzerine kurulan bina veya çadır, ya da ağaç veya bitki dallanı gibi gölge oluşturan farkh unsurlarla yapılabileceği ileri sürülmüştür ${ }^{49}$. Yukarıda verilen hadiste de kaldırılması istenen çadırın mezar üzerine gölge yapması için kurulduğunun belirtilmesi bu bakımdan dikkate değerdir. Bazı surelerde ${ }^{50}$ cennetlerin diğer özelliklerinin yanı sıra gölgelik bir yer olarak da tanımlanması, mezar üzerine düşürülen gölge ile cennet arasında sembolik bir ilişki olabileceğine delil oluşturacak niteliktedir.

Osmanlı sultanlarının mezarlan üzerine otağ kurulmasında Türklerin İslam öncesi defin geleneklerinin mi, yoksa mezar üzerine düşürülen gölgeyle oluşturulan cen-

${ }^{49}$ Danesvari, a.ge., s. 9-17.

${ }^{50}$ Cennet hakkında bilgi veren sureler için bk. http://www.diyanet.gov.tr/kuran/default.asp? mnct=36 Nisa 57: Iman edip salih ameller işleyenleri ise, içinden ırmaklar akan, içlerinde ebedi kalacaklan cennetlere koyacağız. Onlara orada tertemiz eşler vardır. Onlan, koyu gölgeler alunda bulunduracağız.

Rad 35: Allah'a karşı gelmekten sakınanlara va'dolunan cennetin durumu şudur: Onun içinden ırmaklar akar, yemişleri ve gölgeleri devamlıdır. İşte bu Allah’a karşı gelmekten sakınanlann sonudur. Inkar edenlerin sonu ise ateştir.

Insan 14: Czerlerine cennetin gölgeleri sarkmış, cennetin meyveleri (kolayca alınacak şekilde) yakınlaştırlarak hazırlanmıştır.

Müselâı 41: Allah’a karşı gelmekten sakınanlar, gölgeler içinde ve pınar başlanndadırlar.

Vâkı’a 28-34: (Onlar), dikensiz sidir ağaçlan ve meyveleri küme kume dizili muz ağaçlan altında, yayılmış sürekli bir gölgede, çağlayan bir su başında, tükenmeyen ve yasaklanmayan çok çeşitli meyveler içinde ve yüksek döşekler uzerindedirler.

Yàsin 56: Onlar ve eşleri gölgelerde koltuklara yaslanmaktadırlar. 
net imgesinin mi etkili olduğu tartışılması gereken bir konudur. Bu bağlamda hangi geleneğin daha etkili olduğunu anlamak veya en azından bir fikir vermesi açısından Osmanlı sultanlarının definlerindeki diğer uygulamalara bakmak yararlı olacaktır.

Osmanlı cenaze merasimleri incelendiğinde ağlama ve yanıp-yakılma ${ }^{51}$, matem elbisesi giyme $^{52}$ sarık atma ${ }^{53}$, başa toprak serpme ${ }^{54}$, bedeni yaralama ${ }^{55}$, saç kesme ${ }^{56}$ ve çadır devirme ${ }^{57}$ gibi yas göstergesi olan birçok davranı̧ biçimi tespit edilmekte$\mathrm{dir}^{58}$. Bazı merasimlerde cenaze alayını önünde, ölen sultanın kuyruklan kesilen veya

51 Ağlama ve yanup-yakılma bütün cenaze merasimlerinde tespit edilen genel bir yas gösterisidir. I. Murad'ın ölümünün duyulmasıyla çevredekiler feryatlar ve çı̆̆lklarla gözlerinden kanlı yaşlar dökmüşlerdir. II. Murad'ın naşının taşınması sırasında çığlıklar ve inlemeler gök kubbeye yükselmiştir. II. Bayezid babası için ağlamış, yeniçeriler, saray kadınlan ve halayıklar ağlayarak feryat etmişlerdir. I. Selim babası II. Bayezid için sel gibi gözyaşı dökmüs, I. Selim'in ölümunde solaklar feryat figan etmişlerdir. II. Selim'in defin merasimine katılanlar feryat etmiş ve çı̆lıklar atmıştır. III. Murad'ın naşının taşınması sırasında çı̆glıklar ve inlemeler gök kubbeye yükselmiştir. Bk. Vatin-Veinstein, "II. Mehmed'den I. Ahmed'e Osmanlı Padişahlarumın Cenaze Törenleri”, s. 254-257.

${ }^{52}$ Matem elbisesi giyme yas gösterilerinin en önemli unsurlanndan biridir. II. Mehmed'in ölümünde yeniçeriler sank ve giysilerini çıkanp bedenlerini kalın ve kaba abalarla, başlann da siyah örtulerle ortmüşler, vezirler, ulema ve erkân siyah börümcükler (örtüler) getirtip başlarına dolamı̧lardır. II. Bayezid'in naaşı Istanbul'a getirildiğinde I. Selim ve devlet erkân başlanna siyah sank sarmışlardır. I. Selimin ölümünde oğlu I. Süleyman giysilerini çıkarıp yas elbiseleri giymiştir. I. Süleyman'ı ölümünde solaklar börklerini çıkanp başlanna peşkir dolamışlar, II. Selim ise siyah çuha giyip şemle takmıştur. III. Murad ve II. Mehmed babalannın cenaze merasiminde erkânıyla birlikte siyah elbise giyip siyah sank ve șemle takmışlardır. Bk. İsmail Hakkı Uzunçarşlı, Osmanh Devletinin Saray Teşkilath, Turk Tarih Kurumu Yaymlan, Ankara 1984, s. 55; Eşref Buharal,, "Türklerde Matem Alâmetleri", Türk Dünyast Araştırmalan, 65(1990), s. 154; Bağcı, a.g.m., s. 163-168; Ertuğ, a.ge., s. 153-155; VatinVeinstein, "II. Mehmed'den I. Ahmed'e Osmanlı Padişahlannun Cenaze Törenleri", s. 260-264.

${ }^{51}$ I. Selim'in ölümünde bütün solaklar serpuşlanıı yere firlatmışlardır. Bk. Vatin-Veinstein, Osmanlı Padişahlannun Cenaze Törenleri, s. 258.

${ }^{5}$ II. Mehmed oğlu Mustafa'nın öldüğunü oğrenince başına tozlar serpmiştir. II. Mehmed'in ölümünde yeniçeriler, II. Bayezid'ın ölümünde ise sipahiler başlannı toza toprağa belemişlerdir. I. Süleyman'ın ölümünü haber alan yeniçeriler yüzlerini tevazu tozuna surrmüşlerdir. Bk. Vatin-Veinstein, "II. Mehmed'den I. Ahmed'e Osmanlı Padişahlarının Cenaze Törenleri”, s. 258-259.

ss II. Mehmed'in ölümüne yas tutan yeniçeriler göğüslerini yumruklayarak yanaklannı paralamışlar, saray kadınlan ve halayıklar yüzlerini yırtmışlardır. II. Bayezid için sipahiler gögüslerini paralamışlardır. Bk. Vatin-Veinstein, "II. Mehmed'den I. Ahmed'e Osmanlı Padişahlannun Cenaze Törenleri”, s. 255-264.

${ }^{56}$ II. Mehmed'in ölümüne yas tutan saray kadınlan ve halayıklar saçlann kesmişlerdir. Vatin-Veinstein. “II. Mehmed'den I. Ahmed'e Osmanlı Padişahlarnm Cenaze Törenleri”, s. 255-264; Eldem, a.ge., s. 82-86.

${ }^{57}$ I. Selim'in ölümünde bütün çadırlar yıkılmış̧ur. Bk. Vatin-Veinstein, "II. Mehmed'den I. Ahmed'c Osmanh Padişahlanın Cenaze Törenleri”, s. 258.

${ }^{58} \mathrm{Bu}$ tür yas gösterileri sadece Osmanlılara özgü olmayıp Büyük Selçuklu, Anadolu Selçuklu ve Memluklular gibi diğer Tük devletlerinde de tespit edilmiştir. Sultan Tuğrul 1063 ylında ölünce emirler ve hacipler elbiselerini yırtmak istemişlerdir. Sultan Melikşah'ın oğlu Davud'un cenaze merasiminde Türkmenler saçlannı kesmişler ve atlanın alınlanı çizmişlerdir. Melikşah'ın ölüm haberi alınınca Türkmenler atlarının kuyrukların kesip, eyerlerini ters çevirip üstlerine kara örtüler sermişler, kadınlar saçlannı yolarak karalar giymişlerdir. Izzettin Keykavus'un yas merasiminde Alaeddin Keykubad ak atlas giymiş, beyleri ise elbiselerinin üzerine ak gaşyiler çekip börklerini ters giymişlerdir. Mevlana'nın cenaze merasimine katulanlar matem elbisesi giymişler, sarıkların çıkarıp elbiselerini yırtmış ve saçlarını yolmuşlardır. Bk. Buharalı, a.g.m., s. 149-159; Görkem, a.g.m., s. 168-170; Cihan Piyadeoğlu, "Büyük Selçuklular Dünyasında Yas Tutma Âdetleri ve Tanzim Merasimleri" Trakya Universitesi Edebiyat Fakültesi Dergisi, 2/3 (2012), s. 29-41. 
boyanan tersine eyerlenmiş atlarının bulunması ${ }^{59}$, askerlerin yaylarını kırmaları, kırık yayların tabutun üzerine konulması, sultanın yayının ve kılıcının mezarının yanına bırakılması $^{60}$ gibi davranışlar Osmanlı döneminde azımsanmayacak kadar İslam öncesi defin adedi olduğunu göstermektedir ${ }^{61}$.

Osmanlı defin merasimlerinde saptanan bu adetler naaş veya mezar üzerine otağ kurulması uygulamasının da diğerleri gibi İslam öncesi defin gelenekleri ile ilişkili olabileceği kanaatini güçlendirmektedir. Ancak hemen belirtmek gerekir ki Türklerin İslam öncesi defin merasimlerinde görülen birçok uygulama Osmanlı dönemine değin oluşan yeni sosyal şartlar içerisinde değişime uğramıştır. İslam öncesi dönemin ölü çadırlarını da bu bağlam içerisinde ele almak ve değerlendirmek gerekir.

İslam öncesi defin merasimlerinde ölü için kurulan çadırın temel işlevi defin öncesi uygulamalarla ilişkilidir. Ölü çadırlarının içerisinde tahnit, yıkama, kefenleme ve tabuta koyma gibi işlemler yapılarak naaş defin için hazırlanmakta, çevresinde ise yas gösterileri gerçekleşmektedir. Bu uygulamalar bir bütünün parçaları olsa da ölü çadırlarının içerisinde gerçekleştirilen defin öncesi işlemler ile çevrelerinde gerçekleştirilen yas gösterileri birbirinden farklı nitelikte eylemlerdir. Bu ayırım Osmanlı dönemindeki değişimin algılanması açısından da önem taşımaktadır.

Osmanlı döneminde sultanlar için ölü çadırı kurma uygulaması ünik bir durumdur. Özellikle seferde veya başkent dışında gerçekleşen sultan ölümlerinin gizlenmesi ${ }^{62}$ nedeniyle bu uygulamadan özellikle kaçınılmış, 1398 yılındaki Kosova Savaşı sırasında I. Murad için kurulan otağ ${ }^{63}$ dışında sultanlar için ölü çadırı kurulduğuna dair bir bilgi de tespit edilememiştir. Sefer sırasında ölen sultanların definlerinde ölü çadırında

${ }^{59}$ II. Mehmed'in oğlu Mustafa'nun cenaze töreninde tersine eyerlenmiş ve kuyruklan boyanmıs, II. Bayezid ve IV. Murad'n cenaze merasiminde ise sultanın gazaya gittiği atlan tersine eyerlenmiş olarak cenaze alayını önünde yürütmüşür. Bazı kaynaklar sahibinin ölümüne ağhyormuş gibi gözlerinin yaşarmasın sağlamak için atlann burunlanna biber atıldığın belirtmektedir. Bk. Naîmâ Mustafa Efendi, Târih-i Na'imâ (Ravzatü'l-Hüseyin Fi Hulâsati Ahbâri'l-Haffikayn), c. II, haz. Mehmet Ipşirli, Türk Tarih Kurumu Yayınlan, Ankara 2007, s. 943; Şehabettin Tekindağ, "Padişahlar İçin Tertiplenen Türk Usulü Cenaze", Türk Külttürü, 17(1963), s. 47; Vatin-Veinstein, Le Sérail ébranlé Essai sur les morts, s. 417-418.

${ }^{60}$ II. Mehmed ve II. Bayezid'in cenaze alayındaki okçular yaylannı kırmışlardır. Şehzade Ahmed'in oğlu Süleyman'ın cenaze merasiminde kınlan yaylar tabutun üzerine konulmuştur. 1595 ylında I. Süleyman'ın türbesini ziyaret eden Wratislaw von Motrowitz sultanın sandukasının yanında bir yay ve tirkeş ile işli bir kılıç görmüştür. Bk. Tekindağ, a.g.m., s. 46-47; Vatin-Veinstein, Le Sérail ébranlé Essai sur les morts, s. 423-424; Vatin-Veinstein, "II. Mehmed'den I. Ahmed'e Osmanlı Padişahlarının Cenaze Törenleri", s. $280-281$.

${ }^{61}$ Bu tür yas gösterileri diğer Türk devletleri ve topluluklarında da tespit edilmektedir. Bk. Buharalı, a.g.m., s. 149-159; Görkem, a.g.m., s. 157-188.

${ }^{62}$ Sultan ölümlerinin gizlenmesi hakkında bk. Ertuğ, a.ge., s. 150-153.

${ }^{63}$ Osmanlı döneminde naaşı için otağ kurulduğunu bildiğimiz ikinci örnek Şehzade Mustafa'dır. Şehzadenin ölümü babasının otağında gerçekleşmiş ölümün gizlenmesi gibi bir durum söz konusu olmadığı için naaşı üzerine otağ kurulmuştur. Bk. Resim 3 . 
yapılması gereken Osmanlıca tabiriyle «techiz ve tekfin" yani gerektiği durumlarda tahnit, yıkama, kefenleme ve tabuta koyma gibi her türlü defin öncesi işlem, I. Selim ve I. Süleyman örneğinde olduğu gibi sultanın vefat ettiği otağda yapılmıs ve ayn bir ölü çadırı kurulmasına gerek duyulmamıştır.

Eğer sultan İstanbul veya yakınlarında ölmüş ise techiz ve tekfin Topkapı Sarayı'nda yapılmıştır. 17. yüzyılın sonlarına kadar techiz ve tekfinin haremde yapıldığı dışında ayrıntılı bir bilgi yoktur. Konumuz açısından üzerinde durulması gereken uygulama 17. yüzyllın sonlarından itibaren bilgi sahibi olduğumuz tekfinlerin Enderun Avlusu'nda kurulan çadırlarda gerçekleştirildiği durumdur. Dönem kaynaklarından alınan bilgilere göre II. Süleyman (öl. 1691), II. Mustafa (öl. 1703), III. Osman (1757) ve I. Abdülhamid'in (öl. 1789) tekfinleri Enderun avlusunda kurulan çerge ${ }^{6 t}$ veya sayebanlarda ${ }^{65}$ yapılmıştur.

II. Süleyman'ın Topkapı Sarayı Enderun Avlusu'nun Kızlar Ağası Kapısı önüne kurulan çerge içerisindeki tekfini hakkında Silâhdar Mehmed Ağa ${ }^{66}$ tarafindan bilgi verilmektedir:

"Pâdişah-1 mağfurun cenâzesi harem kapısı dâhilinde vaki' darü's-saâde ağası odası önünde kurulan çergeye getirilüb gasline Şeyhülislâm memur iken pir ü alîl olmağla İmam Ali Efendi gasledüb bostancılar imamı Hacı Şaban Efendi su koyub techiz ve tekfini tamam olduğunu arz eylediklerinde ata süvar ve alay köşküne nüzûl ve ikindi namazın eda eyledikden sonra köşk dâhilinde tahtadan vaz' olunan musallaya inüb pâdişâh-1 mağfurun cenâzesin getürdiler. Ve İmam Ali Efendi hâzır olan âyan ve cemaat-i kesîre ile namazın kılub arabaya tahmil eylediler ve penbe ile dört tarafin besleyüb kavi kolanlar ile sarub kokmamak içün altma ve üstüne buz pareleri koydular".

II. Mustafa'nın Topkapı Sarayı Enderun Avlusu'nda Ağalar Camii önündeki meydana kurulan çergedeki tekfinini ise bizzat Silâhdar Mehmed Ağa ${ }^{67}$ yaptırmıştur. Silâhdar kendi yapturdığı tekfini şöyle anlatmaktadır:

"Padişah, silahdar olduğum için cenaze töreninin benim tarafimdan yönetilmesini istemişti. Ben de vezirleri ulema ve büyük rütbedeki memurlan çağırttum. Bunlar saraya gelip Akağalar kapısı dışında toplandıkları sırada, cenazeyi Kuşhâne kapısından çıkartıp, İçoğlanlan cami'i önündeki meydanlığa kurulan çergeye getirttim. Vasiyeti üzerine ve Pâdişahın emri gereğince, Ayasofya şeyhi

${ }^{64}$ Hafif çadır anlammna gelen Farsça bir tabirdir. Çergelerin iki kubbeli bölümden oluşan bir çeşidi karargâhlarda otağ-1 hümayuna giden iki yolun ortasına kurulur ve sultan otağına giderken bu çergenin içinden geçerdi. Bk. Mehmet Zeki Pakalın, Osmanl Tarih Deyimleri ve Terimleri Sözlüğü, c. I, Milli Eğitim Bakanhğı Yayınlan, İstanbul 1993, s. 353.

${ }^{65}$ Büyük çadur anlamında kullanılan Farsça bir tabir olan sayeban gölgelik veya tente manalannda kullanimaktadır. Bk. Pakahn, a.ge., c. III, s. 132-133.

66 "Bk. Silâhdar Findıkhlı Mehmed Ağa, Silahtar Tarihi, c. II, İstanbul 1928, s. 574.

${ }^{67}$ Bk. Silâhdar, Nusretname, c. II, s. 208-209. 
İspirî damadı Mustafa Efendi, Ayasofya başimamı Gonça zade Mustafa Efendi, İmam-i Sultanî Seyyid Mustafa Efendi ve Saray kurralarından Şeyh Mehmed Efendilerin yardımıyla yıkanı kefenlendi. Tabutuna üç sorguçlu mücevveze konulduktan sonra kaldırildı".

Başbakanlık Osmanlı Arşivi’ndeki 350 numaralı cülûs merasimlerine dair Sadaret Defteri'ndeki bilgiye göre III. Osman'ın tekfini Topkapı Sarayı Enderun Avlusu'nda kurulan bir sayeban içerisinde yapılmıştur ${ }^{68}$.

"na'ş-1 gufran-nakş dahi bi-izn-i hümâyûn zülüfliyân kapusu kurbunda vâki" kızlar kapusu ta'bîr olunur kapudan ihrâc ve mermer sütûnlar altında darb olunan sayebân derûnunda şehremîni ve yazıcı efendi ma'rifetleriyle gasle mübâşeret esnâsında feth-i hakānîden beru selâtîn-i Osmâniyye'den ve gerek şehzade-i cüvanbahtândan 'âzim-i şehrâh-1 cinân olanların na'ş-1 gufran-nakşları mevzû'-1 tahta-i tenşüy oldukta yeniçeriyân-1 dergâh-1 âli ocağı kullanndan yeniçeri ağası ve sekbanbaşı ve kul kethüdâsı ağa kullan dahi gelip bir kerre dahi mübârek cemâl-i mağfiret-iştimallerin müşâhede ile merasîm-i hukûk-1 bendegîyi icrâ sûretinde resm-i hakk-1 vedâ'ı edâ eylemeleri Saray-1 Hümâyûn'da öteden berü mer'î olan hâlâttan olmağla bu dahi Enderûn-1 Hümâyûn tarafindan sudûr eden izn-i hümâyûn üzere mûmâileyhüm gelip müşâhede ve der-'akab 'avdet eyledikten sonra gasle şürû‘ olunmağla ba'de'l-hitâm kaldınlıp babüssa'âde semtinde mevzû‘ musallâya îsâl olunurken"

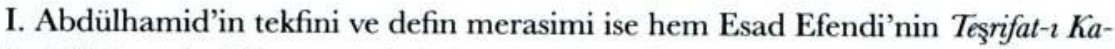
dime'sinde ${ }^{69}$, hem de 350 numaralı Sadaret Defteri'nde ${ }^{70}$ benzer şekilde anlatılmıştır. Defterlere göre I. Abdülhamid'in tekfini de Topkapı Sarayı Enderun Avlusu'nda kurulan bir sayeban içerisinde gerçekleşmiştir.

"Bu esnâda Zülüfliyân kapusu kurbunda vâk'i kapusundan merhum efendimizi ihrâc ve mermer sütunlar altunda darb olunan sâyebân derûnunda Yazıcı efendi marifetiyle gasle mübaşeretten mukaddem erkân-1 devlet cemal-i mağfiret iştimallerin müşahede ile merasim-i hukuk-1 bendegiyi icra suretinde resm-i hakk-1 vedâ-1 eda eylemeleri emr-i hümayuna muhtaçtur deyu kisedar-1 teşrifat, saâdetlû babü's-saâde ağasına ifade ve ağay-1 müşarünileyh dahi şevketlû efendimize istâzan eylediklerinde "teşrifat ne ise icra olunsun» deyu izin sadır olduğunu tefhim eylemeleriyle sayeban altında, vefat eyledikleri elbise ile şeyhulislâm efendi ve kaymakam paşa ve kaptan paşa ve sudur-1-kiram ve defterdar ve reis-ül-küttâb ve ocak ağaları varub rüyet ve bâdeddua avdet eylediklerinde meşâyih-i selâtîn ve imâm-1 dîvânhâne-i saray-1 hümâyûn ve imam-ı şehriyârî efendiler mübâş̧eretiyle ve saâdetlü dârü's-saâde ağası nezâretiyle gasle şürû' olunmağla"

${ }^{68}$ Mehmed Es'ad Mehdi, Sadaret Teşrf́ât Defteri, haz. Uzeyir Yuldırnm, ed. Abdülkadir Ozcan, Kültür ve Turizm Bakanlğı Yayınlan, İstanbul 2007, s. 21-22 (http://ekitap.kulturturizm.gov.tr/belge/1-83610/ mehmed-esad-medhi---sadaret-tesrifat-defteri.html).

${ }^{69}$ Esat Efendi, Teşrifat-i kadime, Matbaa-yı Âmire, İstanbul 1287 (1870), s. 115-116.

${ }^{70}$ Mehmed Es'ad Mehdî, a.ge., s. 98-99. 
Osmanlı sultanlarının 18. yüzyldaki defin merasimleri D'Ohsson ${ }^{71}$ tarafindan da ayrınthl olarak anlatılmıştır. D'Ohsson'un verdiği bilgiye göre; harem ağaları tarafindan harem kapısına kadar getirilen naaş bostancılar tarafindan alınarak harem yanındaki revakların altına kurulan çadıra götürülmektedir. Burada görevliler tarafindan naaş tetkik edilmektedir. Daha sonra saray hocaları tarafindan su ve sabunla yıkanmakta ve kokular sürülerek defin için hazırlanmaktadır ${ }^{72}$.

Yukarıdaki anlatılardan tekfinlerinin çadırlarda yapılmasının ölen sultanın naaşının görülerek ölüm sebeplerinin saptanması gibi bir hukuksal süreçten kaynaklandığı anlaşılmaktadır. Uzunçarşılı ${ }^{73}$ teşrifat defterlerinde belirtildiği gibi sultanın suikasta uğrayıp uğramadığının yeniçeri ocağı tarafindan bilinmesinin bir kanun olması nedeniyle yeniçeri ağası, sekbanbaşı ve kul kethüdasının ölen sultanın cesedini elbisesiyle birlikte görmelerinden sonra tekfin edilerek defin işlemlerinin yapıldığın belirtmekte, D’Ohsson ise bu uygulamanın Sultan İbrahim'in öldürülmesinden sonra (öl. 1648) usul haline geldiğini ifade etmektedir ${ }^{74}$.

Topkapı Sarayı Enderun Avlusu'nun revakları altunda kurulan çerge veya sayebanlar biçimsel olarak ölü çadırn geleneğini haturlatsa da bu çadırlarda sadece görevliler bulunmakta, çadır çevresinde yas gösterisi yapılmamakta ve bunlar sadece tekfin için kullanulmaktadır. Dolayısıyla bu çadırlar ile İslam öncesi defin uygulamalarındaki ölü çadırları arasında bir ilişki yoktur. İslam öncesi defin merasimlerinde ölü çadırnnı çevresinde yapllan yas gösterileri ${ }^{75}$ Osmanlı döneminde ölüm haberinin duyurulması ile başlayıp defin merasimi sırasında devam etmektedir. Yas gösterilerinin bir parçası olan aş verilmesi, fakir fukaranın doyurulması ve sadaka dağıtılması gibi hayır işleri ise defin sonrasında mezar üzerine kurulan otağın çevresinde gerçekleşmektedir ${ }^{76}$. Bu yönleri ile otağlar ile İslam öncesi defin merasimlerindeki ölü çadırlan benzer özellikler göstermektedir.

Mezar üzerine kurulan otağların diğer bir işlevinin sultan mezarlarını görünür kılmak ve korumak olduğunu düşünmek gerekir. Aksi takdirde mezarlar her türlü taciz ve saldırıya açık olacaktır. Celâl-zâde ${ }^{77}$ ve Selaniki'nin ${ }^{78}$ verdiği bilgiler de otağlar için

" 1740 yllında İstanbul'da doğan Ignatius Mouradgea D'Ohsson Ermeni asıllıdır. Babası İsveç vatandaşlğğna girmiş ve İsveç'in İzmir konsolosu olmuştur. D'Ohsson'un kendisi de İsveç'in İstanbul maslahatgüzarlı̆ı̆m yapmıs ve 1807 yllında Paris'te ölmüştür. Bk. Kemal Beydilli, "Ignatius Mouradgea D’Ohsson (Muradcan Tosunyan) Ailesi hakkında kayıtlar, "Nizâm-1 Cedìd'e Dâir Lâyihası ve Osmanlı İmparatorluğundaki Siyâsi Hayat", Tarih Dergisi, 34 (1984), s. 247-314.

${ }^{72}$ M. D'Ohsson, Haremi-i Humâyan, şev. Ayla Düz, İstanbul 1972, s. 21.

${ }^{13}$ Uzunçarşili, a.ge., s. 53-54.

${ }^{74}$ M. D'Ohsson, a.ge., s. 21.

${ }^{75}$ Bk. Tryjarski, a.ge., s. 147-166.

${ }^{76}$ IIII. Murad'ın defin merasiminde ölenin ruhu için aş verilip hayır işleri yapılmışır. Bk. Selâniki, a.ge., s. 457.

${ }^{77}$ Celâl-zâde, a.ge., s. 222, 453.

${ }^{78}$ Selâniki, a.ge., s. 457. 
bekçiler tayin edilerek güvenliklerinin sağlandığını göstermektedir. Dolayısıyla mezar üzerine kurulan otağlar bir ritüel olmanın yanı sıra, türbeleri inşa edilene kadar sultan mezarlarını görünür kılmak ve korumak gibi bir işlevle de kullanılmışlardır. Daha sonra bu otağlar kaldırılacak ve yerlerine sultanların kalıcı türbeleri inşa edilecektir. Bu nedenle sultan mezarları üzerine kurulan otağları geçici türbeler olarak nitelemek uygun olacaktır.

Mezarı üzerine otağ kurulduğunu bildiğimiz sultanlar için yaptırılan türbelerin inşa tarihleri de bu hususu doğrulamaktadır. 1520 'de vefat eden I. Selim'in türbesi 1522 'de, 1566'da vefat eden I. Süleyman'ın türbesi 1568 'den sonra, 1574 yllında vefat eden II. Selim'in türbesi 1576'da, 1595'de vefat eden III. Murad'ın türbesi 1600'de, 1603'de vefat eden III. Mehmed'in türbesi 1608/1609'da ve 1839'da vefat eden II. Mahmud'un türbesi ise 1840 yılında tamamlanmıştır ${ }^{79}$. Bu nedenle ölümleri ile türbelerinin inşa tarihleri arasındaki zaman süresinde sultan mezarlarının görünür kılınması ve korunması için otağ kurulması bir ritüel olmanın yanı sıra bir gereklilik olarak da gözükmektedir.

Otağların yerlerine kalıcı türbelerin inşa edilmesi tamamen yeni sultanın takdirinde olmakla birlikte ${ }^{80}$ bu işlemin de belirli bir ritüel içerisinde gerçekleştiği anlaşılmaktadır. I. Selim ve III. Murad'ın türbelerinin inşasıyla ilgili anlatılara göre kalıcı türbelerin inşası için otağ ve çevresinde gerçekleşen yas gösterileri ile Kur'an okunması ve diğer hayır işlerinin son bulması beklenmektedir.

Solak-zâde I. Selim'in cenaze merasimini anlatırken “....kark gün muhâfazadan sonra, hazret-i padişah peder-i saadet-intizâmlannın merkadi ciwarnnda hukuk- - ebeveti eda üzere bir ali câmi'-i cennet makam ve imaret-i güzin-i hayır-encam yapturdalar" şeklinde I. Selim'in defninden sonra otağ ve çevresindeki merasimlerin kırk gün kadar sürdügünü, bu sürenin bitmesinden sonra içerisinde sultanın türbesinin de bulunduğu külliyenin inşaatına başlandığı belirtilmektedir ${ }^{81}$.

Selaniki ${ }^{82}$ ise III. Murad'ın türbesinin inşasıyla ilgili olarak aşağıdaki bilgiyi vermektedir.

\footnotetext{
${ }^{79}$ Hakkı Onkal, Osmanl Hanedan Türbeleri, Kültür Bakanlığı Yayınlan, Ankara 1992, s. 123, 167, 180, 190, 259.

${ }^{80}$ Defin merasiminin yapılması için cülus törenin beklenmesi bu bakımdan önemlidir. Orneğin II. Süleyman'ın defin yeri II. Ahmed tarafindan belirlenmiştir. "götürüb yollarda kimseyi incitmeyin Sultan Süleyman türbesinde defnetsinler diye tenbih buyurdular". Bk. Silâhdar, Silahtar Tarihi, s. 574.

${ }^{81}$ İçerisinde sultanın türbesinin de yer aldığı külliye I. Süleyman tarafindan sultanı ölümünden sonra inşa ettirilmiştir. Bk. Doğan Kuban, "Sultan Selim Külliyesi", Dünden Bugüne İstanbul Ansiklopedisi, 7(1994), s. 62-63.

${ }^{82}$ Selâniki, a.g.e., s. 424.
} 
"Merhûm ve mağfûrun leh Sultân Murad Han'un kırkı tamâm olup, türbe-i şerîf binâsına mübâşeret olunduğıdur.

Ve şehr-i cumâdelâhirenün altuncı gün merhûm ve mağfûrun leh Sultân Murad Han -tâbe serâhu- türbesine tilâyet-i Kur'ân-1 azîm eyleyen bekciler eyyâm-1 erba'îni tamâm idüp, rûh-1 pür-futûhlan içün aşlar pişüp, fukarâ vü mesâkîn it'am olunup, ma'hûd olan ca'izeleri virilüp sa'ir hasenât ve tasaddukât tevzi' olundukdan sonra du'a ve senâlar ile ihtitâm eylediler ve ser-mi'mârân ve mühendisân-1 devrân Davud Ağa türbe-i şerifün resmini şeş-kûşe üzre ta'yîn eyleyüp, binası içün esbâb u edevât ihzâr eyleyüp, temeli bırağılup, binâsına şurû‘ olund. Fi't-târîhi'l mezbûr."

Yukarıda metinlerden de görüleceği gibi türbe inşaatlarının başlayabilmesi için en az kırk gün kadar beklenmesi gerekmektedir. Kuşkusuz bu süre matematiksel ${ }^{83}$ bir hesaptan çok sembolik bir değere sahiptir. Anadolu'da kırkı çıkmak tabirinin gerek ölüler, gerekse de yeni doğmuş bebekler için yaygın olarak kullanılması, o gün mevlit veya yasin okutulması, hatim indirilmesi, yemek verilmesi ve helva dağıtılması gibi gelenekler dikkate alındığında bu sürenin önemi daha anlaşılır bir hale gelmektedir ${ }^{84}$.

Yukarıda bahsedilenler dışındaki Osmanlı sultanlarının mezarları üzerine otağ kurulup kurulmadığı hakkında kesin bir bilgi yoktur. Ancak bu sultanların ölüm tarihleri, defin yerleri ve türbelerinin inşa tarihleri mezarlan üzerine otağ kurulup kurulmadığı hakkında fikir edinmemize olanak sağlayacak niteliktedir. Bu hususlar değerlendirildiğinde Osman Gazi (öl. 1324) $)^{85}$, I. Murad (öl. 1389) ${ }^{86}$, I. Bayezid (öl.

8s Vatin ve Veinstein'in Selânikî'nin III. Murad'ın türbesinin inşasıyla ilgili olarak verdiği tarihle (cumâdelahirenün altına gümü), sultanın defin tarihi arasındaki sürenin metinde belirtildiğinin aksine kırk gün olmadığın tespit etmiştir Bk. "II. Mehmed'den I. Ahmed'e Osmanlı Padişahlarının Cenaze Törenleri”, s. 289.

${ }^{84}$ Bk. Sedat Veyis Ornek, Anadolu Folklonunda Olüm, Ankara Oniversitesi Dil ve Tarih-Coğrafya Fakültesi Yayınlan, Ankara 1979, s. 78-79; Annemarie Schimmel, Sayzlann Gizemi, çev. Mustafa Küpuşoğlu, Kabalc Yaynlan, Istanbul 2000, s. 265-273.

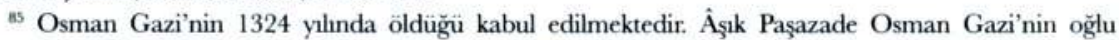
Orhan'a defniyle ilgili olarak "Oğul Orhan' Ben öldü̈üüm zaman beni Bursa'daki o Gümüşlü kubbenin altnna koyacakssn" şeklindeki vasiyetini nakleder. Anlaşıldığı kadarıyla Osman Gazi 1324 yılında vefat ettiğinde geçici olarak Söğüt'te defnedilmiş, 1326'da Bursa'nın fethinden sonra vasiyeti gereği naaşı eski bir Bizans manastın olan Gümüşlü Kubbe'ye nakledilmiştir. Anonim Teuânîh-i Al-i Osman'da yer alan bilgi de bu yöndedir. Anonim yazar "Osman vasiyet itdi kim "Beni Bursa'da gümiş kubbe altına kon" didi. Amma ba'zular dirler. "Sögütcük'de defn itdiler" şeklinde hem Osman Gazi'nin vasiyeti, hem de ilk defin yeri hakkanda bilgi vermiştir. Bk. Âşık Paşazade, a.ge., s. 87-88; Anonim, Taainh -i Al-i Osman, (Neş. F. Giese, Haz. Nihat Azamat), Marmara Úniversitesi Yaynlan, Istanbul 1992, s. 15; Halil Inalcık, "Osman I", Tiurkije Divanet Vakfi İslam Ansiklopedisi, 33(2007), s. 451. Osmanl kaynaklannda Gümüşlü Kubbe adıyla geçen yapı Bursa Aziz Yahya (Hagios Ioannes) Manastır'dır. Bk. V. Macit Tekinalp, "Remodelling The Monastery of Hagios Ioannes In Prousa Ad Olympum (Modern Bursa, Türkiye)", Trudy Gosudarstvennogo Ermitaja- The State Hermitage Papers, 53(2010), s. 162-177.

${ }^{86}$ Kosova savaşı sırasında şehit olan sultanın naaşı Bursa'ya getirilmiş ve yaptırdığı külliyenin yakınlannda hazırlanan mezara defnedilmiş, türbesi ise oğlu I. Bayezid tarafindan ölümünden sonra yaptunlmıştur. Bk. Onkal, a.ge., s. 278-281. 
1402) ${ }^{87}$, II. Murad (öl. 1451) $)^{88}$, II. Mehmed (öl. 1481) ${ }^{89}$, II. Bayezid (öl. 1512) ${ }^{90}$ ve I. Ahmed'in (öl. 1617) ${ }^{91}$ türbeleri oğulları tarafindan ölümlerinden sonra inşa ettirildiği için görünür kılınmalanı ve korunmaları amacıyla mezarlan üzerine otağ kurulması muhtemel diğer sultanlardır.

Orhan Gazi (öl. 1362) ${ }^{92}$, I. Mehmed (öl. 1421) ${ }^{93}$, II. Osman (öl. 1622) ${ }^{94}$, I. Mustafa $\left(\text { öl. 1639) }{ }^{95} \text {, IV. Murad (öl. 1640) }{ }^{96} \text {, İbrahim (öl. 1648) }{ }^{97} \text {, II. Süleyman (öl. 1691) }\right)^{98}$, IV. Mehmed (öl. 1693) $)^{99}$, II. Ahmed (öl. 1695) ${ }^{100}$, II. Mustafa (öl. 1703) ${ }^{101}$, III. Ahmed

${ }^{87}$ Akşehir'de vefat eden sultanın Bursa'ya gönderilen naaşı 1403/1404 yulında zaviyesinin yakınına defnedilmiş, türbesi oğlu Süleyman Çelebi tarafindan 1406 ylında inşa ettirilmiştir. Bk. Onkal, a.ge., s. 55.

${ }^{88}$ Bursa'da defnedilmiştir. Türbesinin oğlu II. Mehmed tarafindan ölümünden sonra yapturıldığı kabul edilmektedir. Bk. Ökal, a.ge., s. 81.

a9 Ístanbul'da vefat etmiş ve inşa ettirdiği külliyenin mihrap duvan önündeki bahçeye defnedilmiştir. Sultanu 1766 depreminde yıkıldı̆ı bilinen türbesi oğłu II. Bayezid tarafindan inşa ettirilmiştir. Bk. Onkal, a.ge., s. 225.

${ }^{90}$ Corlu'da vefat eden sultanın naaşı İstanbul'a getirilmiş ve inşa ettirdiği caminin kıble tarafinda defnedilmiştir. Sultanın türbesi oğlu I. Selim tarafindan 1513 yıl sonlarına doğru yapturlmışur. Bk. M. C. Şahabeddin Tekindağ, "Bayezid'in Olümü Meselesi", Tarih Dergisi, 24(1970), s. 1-16; Ônkal, a.ge., s. 112.

${ }^{9}$ İstanbul'da vefat eden sultanın naaşı inşa ettirdiği külliyenin kuzeydoğusuna defnedilmiş, türbesi oğlu II. Osman tarafindan 1619 ylında yaptunlmıştur. Bk. Onkal, a.ge., s. 198.

${ }^{92}$ Bursa'da vefat etmiş ve babasının gömüldüğü manastura defnedilmiştir. Bk. Halil İnalcık, "Orhan”, Tïrkiye Diyanet Vakfi Islam Ansiklopedisi, 33(2007), s. 383; V. Macit Tekinalp, a.ge., s. 166-169.

${ }^{93}$ Edirne'de vefat etmiş, naaşı Bursa'ya nakledilerek inşa edilmekte olan türbesine defnedilmiştir. Sultanın türbesinin oğlu II. Murad tarafindan tamamlatıldı̆̆ kabul edilmektedir. Ancak Müneccimbaşı gibi bazı tarihçilerin sultanın naaşını hazır olan türbelerine defnedildiğini ifade etmeleri defin sırasında türbenin tam olarak bitirilmese de varlı̆ım göstermektedir. Bk. Müneccimbaşı Ahmed b. Lütfullah, Camiü'd-Diüvel Osmanh Tarihi (1299-1481), yay. Ahmet Ağırakça, İnsan Yayınlan, İstanbul 1995, s. 182-183; Önkal, a.ge., s. 64 .

94 Istanbul'da çıkan bir isyanda Yedikule'de boğularak öldürülmüş ve naaşı babası I. Ahmed'in türbesine defnedilmiştir. Bk. Feridun Emecen "Osman II", Tïrkije Diyanet Vakfi İslam Ansiklopedisi, 33(2007), s. 455.

${ }^{9}$ İstanbul'da vefat etmiş, naaşı Ayasofya camiye çevrildikten sonra kandil yağlarunun depolandiğı ambar olarak kullanılan eski vaftizhane binası türbeye dönüştürülerek defnedilmiştir. Bk. Semavi Eyice, "Mustafa I-Sultan İbrâhim Türbesi", Dünden Bugüne İstanbul Ansiklopedisi, 5 (1994), s. 543-545.

${ }^{96}$ İstanbul'da vefat eden sultanun naaşı I. Ahmed Türbesi'ne defnedilmiştir. Bk. Ziya Yılmazer, "Murad IV", Türkiye Diyanet Vakfi Islam Ansiklopedisi, 31(2006), s. 182.

${ }^{97}$ İstanbul'da idam edilerek naaşı kendi adıyla anılacak olan I. Mustafa Türbesi'ne defnedilmiştir. Bk. Eyice, "Mustafa I-Sultan İbrâhim Türbesi", s. 543-545.

${ }^{98}$ Edirne'de vefat eden sultanın naaşı İstanbul'a getirilerek I. Süleyman Türbesi'nde defnedilmiştir. Bk. Silâhdar, Silahtar Tarihi, c. II, s. 574.

${ }^{99}$ Edirne'de vefat eden sultanın naaşı İstanbul'a getirilmiş ve annesi Hatice Turhan Valide Sultan'ın türbesinde defnedilmiştir. Bk. Abdülkadir Özcan, "Mehmed IV", Tü̈kìye Diyanet Vakfi İslam Ansiklopedisi, 28(2003), s. 417.

${ }^{100}$ Edirne'de vefat eden sultanın naaşı İstanbul'a getirilerek I. Süleyman Türbesi'nde defnedilmiştir. Bk. Silâhdar, Nusretname, c. I, s. 3-4.

101 İstanbul'da vefat eden sultanın naaşı Hatice Turhan Valide Sultan Türbesi'nde defnedilmiştir. Bk. Abdülkadir Ozcan, "Mustafa II", Tiürkiye Diyanet Vakfi Islam Ansiklopedisi, 31(2006), s. 279. 
$(\text { öl. 1736) })^{102}$, I. Mahmud (öl. 1754) ${ }^{103}$, III Osman (öl. 1757) ${ }^{104}$, III. Mustafa (öl. 1774) ${ }^{105}$, I. Abdülhamid (öl. 1789) ${ }^{106}$, III. Selim (öl. 1808) $)^{107}$, IV. Mustafa (öl. 1808) ${ }^{108}$, I. Abdülmecid (öl. 1861) $)^{109}$, I. Abdülaziz (öl. 1876) ${ }^{110}$, V. Murad (öl. 1904) $)^{111}$, II. Abdülhamid

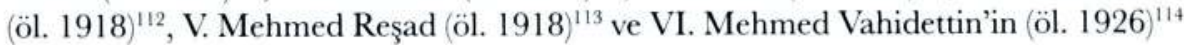
naaşlarn ise bir bina veya türbeye defnedilmiştir. Bu nedenle muhtemeldir ki mezarları üzerine otağ kurulmasına gerek duyulmamıştır.

Bu çerçevede mezan üzerine otağ kurulan ilk sultan olarak 1324 yllında ölen Osman Gazi’yi kabul etmek gerekir. Mezarı üzerine otağ kurulduğunu bildiğimiz son sultan ise 1839 yilında ölen II. Mahmud'dur. Bu tarihten sonra ölen sultanların mevcut türbelere defnedilmeleri nedeniyle naaşlan üzerine otağ kurulmasını gerektirecek bir durum yoktur.

Mezar üzerine kurulan otağların Osmanlı dönemindeki ikonografisi de üzerinde durulması gereken konulardan biridir. Osmanlı kaynaklarında üzerine otağ kuru-

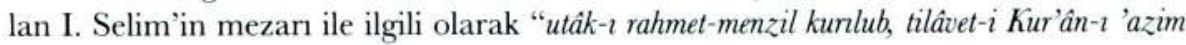

${ }^{102}$ İstanbul'da vefat eden sultanun naaşı Hatice Turhan Valide Sultan Turbesi'nde defnedilmiştir. Bk. Münir Aktepe, "Ahmed III", Türkiye Diyanet Vakfi Islam Ansiklopedisi, 2(1989), s. 37.

${ }^{103}$ Istanbul'da vefat eden sultanın naaşı Hatice Turhan Valide Sultan Türbesi'nde defnedilmiştir. Bk.

Abdülkadir Ozcan, "Mahmud I", Tuirkiye Diyanet Vakfi İlam Ansiklopedisi, 27(2003), s. 351.

Dünden Bugüne Istanbul Ansiklopedisi, 5(1994), s. 509.

${ }^{104}$ Istanbul'da vefat eden sultanm naaşı Hatice Turhan Valide Sultan Türbesi'nde defnedilmiştir. Bk.

Fikret Sancaoğlu, “Osman III", Türkiye Diyanet Vakfi Islam Ansiklopedisi, 33(2007), s, 458.

${ }^{105}$ İstanbul'da vefat eden sultanın naaşı Laleli'de 1763 yılında inşa ettirdiği türbesine defnedilmiştir.

Bk. Onkal, a.g.e., s. 220-224.

106 İstanbul'da vefat eden sultanın naaşı Bahçekapı'da 1780 yılında inşa ettirdiği türbesine defnedilmiştir. Bk. Onkal, a.g.e., s. 231-236.

${ }^{107}$ Istanbul'da vefat eden sultanın naaşı babası III. Mustafa'nın Laleli'deki türbesine defnedilmiştir. Bk. Kemal Beydilli, "Selim III", Türkiye Diyanet Vakfi Islam Ansiklopedisi, 36(2009), s. 420-425.

${ }^{100}$ İstanbul'da vefat eden sultanın naașı babası I. Abdülhamid'in türbesine defnedilmiştir. Bk. Kemal Beydilli, "Mustafa IV", Türkiye Diyanet Vakfi Islam Ansiklopedisi, 31(2006), s. 284.

${ }^{109}$ İstanbul'da ölen sultanın naaşı, I. Selim Türbesi'nin yanında daha önce şehzadeleri için inşa ettirdiği türbeye defnedilmiştir. Bk. Cevdet Pasa, Tezâkir, 13-20, yay. Cavit Baysun, Türk Tarih Kurumu Yaymnlan, Ankara 1986, s. 140-142; Onkal, a.ge., s. 262-264; Servet Yanatma, a.gt., s. 18-26.

${ }^{10}$ İstanbul'da intihar eden sultanın naaşı Divanyolu'ndaki II. Mahmud Türbesi'ne defnedilmiştir. Bk. Haluk Y. Şehsuvaroglu, Sultan Aziz; Hususí, Siyasi Hayatz, Deori ve Ölümü, Hilmi Kitabevi, İstanbul 1949, s. 140; Eldem, a.ge., s. 192-193; Yanatma, a.gt., s. 26-36. Türbesi için bk. Önkal, a.ge., s. 258.

111 Istanbul'da vefat eden sultanın naaşı 19. yüzylın başlannda Hatice Turhan Valide Sultan Türbesi'ne ek olarak inşa edilen Cedid Havatin Türbesi'nde defnedilmiştir. Bk. Cevdet Küçük, "Murad V", Türkiye Diyanet Vakfi Islam Ansiklopedisi, 31(2006), s. 185.

112 İstanbul'da vefat eden sultanın naaşı Divanyolu'ndaki II. Mahmud Türbesi'ne defnedilmiştir. Bk. Ahmet Refik, "Sultan Abdülhamid'in Na'şı Onünde," Tarih Dünyast, 1(1950), s. 95-99; Yanatma, a.g.t., s. 52-72.

${ }^{113}$ Istanbul'da vefat etmiş naaşı sağken 1913-1914 yllında inşa ettirdiği türbesine defnedilmiştir. Bk. Ali Vâsıb Efendi, Bir Şehzadenin Hâtrâtt-Vatan ve Menfáda Gördüklerim ve Işsittiklerim, haz. Osman Selahaddin Osmanoğlu, Yapı Kredi Yayınlan, İstanbul 2004, s. 79-82; Onkal, a.ge., 282-287.

${ }^{114}$ San Remo'da vefat eden sultanın naaşı Şam'da Süleymaniye Külliyesi avlusuna defnedilmiştir. Bk. Necdet Sakaoğlu, "Mehmed VI (Vahideddin)", Diunden Bugüne İstanbul Ansiklopedisi, 5(1994), s. 354. 
içün hâfizlar ve hârisler ta'yîn olunub, makâm-ı behişt-berîn zuhur eyledi" 15 ve III. Murad'nn

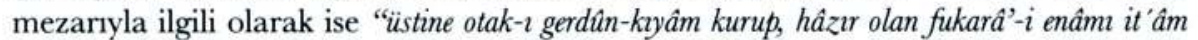

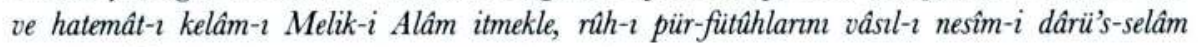
eylediler" "16 şeklinde cennet benzetmesi yapılmıştır.

$\mathrm{Bu}$ anlatımlarda otağ kurularak oluşturulan mekâna cennet benzetmesi yapılsa da cennet imgesinin otağla düşürülen gölgeyle ilişkili olduğuna dair bir veri yoktur. Bu nedenle bazı tarihçiler tarafından veya türbe kitabelerinde sultan türbelerine yapılan cennet benzetmesini otağ veya bina ile düşürülen gölgeden çok oluşturulan mekânın güzelliği ile ilişkilendirmek gerekir. Örneğin Şehzade Mustafa Türbesi kitabesinde geçen "Şah Selim han bin Süleyman emredüb, Oldu hos bu revza cennetnuma" 117 ve II. Selim Tür-

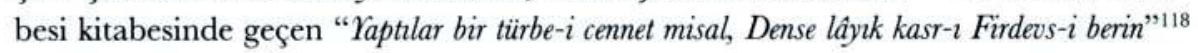
şeklindeki ifadeler de cennet benzetmesinin otağ veya bina ile düşürülen gölgeden çok oluşturulan mekânın güzelliği ile ilişkili olduğunu göstermektedir. Kaldı ki güzelliğini belirtmek için cennet benzetmesi yapılması, Anadolu'da yaygın bir ifade biçimidir.

Mezar üzerine kurulan otağların ikonografisi bağlamında Nusretnâme'de geçen ifadeleri de dikkate almak gerekir. Silahdar'in ${ }^{119}$ ifadesine göre II. Mustafa askerlerin maneviyatını yükseltmek ve onları savaşa teşvik için bazı beylerin cenazelerini kendi otağı içinde hazırlattığı kabirlere defnettirmiştir. Dolayısıyla mezar üzerine kurulan otağlar sultani bir imge, bir itibar ve yüceltme unsuru olarak da değerlendirilmelidir. I. Süleyman'nın Şehzade Mustafa'nın naaşı üzerine, Uyvar seferinde ise şehit mezarlan üzerine otağ kurulmasını da otağın sağladığı prestij ile ilişkilendirmek gerekir. Kaynaklarda sultanlar ve şehitler dışında naaş veya mezar üzerine otağ kurulduğuna dair bilgi bulunmaması da otağların sultani bir imge, bir itibar ve yüceltme unsuru olduğunu doğrulamaktadır.

Sonuç olarak; Türklerin İslam öncesi defin merasimlerinde önemli bir yeri olan ve İslamiyetin kabulünden sonra da sürdürülen naaş üzerine otağ kurma geleneği, Osmanlı dönemindeki yeni sosyal şartlar gereğince değişime uğrayarak yerini mezar üzerine kurulan otağlara bırakmıştır. Bu otağlar Osmanlılar tarafindan sultani bir imge, bir itibar ve yüceltme unsuru olmasının yanı sıra, sultan mezarlarını görünür kılmak ve korumak gibi bir işlevle de kullanılmış, böylece kökleri yüzyllar öncesine değin giden bir gelenek mevcut koşullar içerisinde yeniden şekillenerek varlığını uzun yllar devam ettirmiştir.

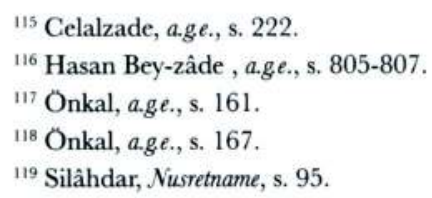




\section{KAYNAKLAR}

Ahmet Lütfi Efendi, Vak'anüvis Ahmed Lütfi Tarihi, c. 6-7-8, haz. Yücel Demirel, Tarih Vakfi-Yapı Kredi Yayınlan, İstanbul.

Ahmet Refik, "Sultan Abdülhamid'in Na'şı Önünde," Tarih Dünyas, 1(1950), s. 95-99.

Aktepe, Münir, “Ahmed III", Türkiye Diyanet Vakfi Íslam Ansiklopedisi, 2(1989), s. 34-38.

Akyıldız, Ali, "Sultan II. Mahmud'un Hastalığı ve Ölümü,” Türk Kïlttürü İncelemeleri Dergisi, $4(2001)$, s. 49-84.

Ali Vâsıb Efendi, Bir Şehzadenin Hâtrâth-Vatan ve Menfâda Gördüklerim ve İşittiklerim, haz. Osman Selahaddin Osmanoğlu, Yapı Kredi Yayınları, İstanbul 2004.

Anonim, Tevârîh-iÂl-i Osman, neş. F. Giese, haz. Nihat Azamat, Marmara Üniversitesi Yayınlan, İstanbul 1992.

Âşık Paşazade, Osmanoğullan'nın Tarihi, haz. Kemal Yavuz-M. A. Yekta Saraç, K Kitaplı̆ğ, İstanbul 2003.

Atl, Esin, The Age of Süleyman the Magnificent, National Gallery of Art, Washington 1987.

Aybakan, Bilal, "Şâfî", Türkiye Diyanet Vakfi İslam Ansiklopedisi, 38(2010), s. 223-233.

Azarpay, Guitty, Sogdian Painting the Pictorial Epic in Oriental Art, University of California Pres, London 1981.

Bağcı, Serpil, "İslam Toplumlarında Matemi Simgeleyen Renkler: Mavi, Mor ve Siyah", Cimetières et traditions funéraires dans le monde islamique Islam Diünasinda Mezarlkklar ve Defin Gelenekleri, c. II, ed. Jean-Louis Bacqué-Aksel Tibet Ankara, Türk Tarih Kurumu, 1996, s. 163-168.

Bağcı, Serpil, Filiz Çağman-Günsel Renda ve Zeren Tanınd, Osmanl Resim Sanatı, ed. Serpil Bağcı, Kültür ve Turizm Bakanlığı Yayınlan, İstanbul 2006.

Bayat, Fuzuli, Türk Mitolöik Sistemi 1 (Ontolöik ve Epistemolöik Bağlamda Türk Mitolö̈isi), Ötüken Neşriyat, İstanbul 2007.

Beydilli, Kemal, “Ignatius Mouradgea D’Ohsson (Muradcan Tosunyan) Ailesi hakkında kayitlar, "Nizâm-1 Cedîd'e Dâir Lâyihası ve Osmanlı İmparatorluğundaki Siyâsi Hayatı", Tarih Dergisi, 34 (1984), s. 247-314.

—_, "Mustafa IV", Türkiye Diyanet Vakfi İslam Ansiklopedisi, 31(2006), s. 283-285.

—_, "Selim III", Türkiye Diyanet Vakfi Íslam Ansiklopedisi, 36(2009), s. 420-425.

Buharah, Eşref, "Türklerde Matem Alâmetleri”, Türk Diünyast Araşttrmalan, 65(1990), s. 149-159.

Celâl-zâde Mustafa, Selim-nâme, haz. Ahmet Uğur-Mustafa Çuhadar, Kültür Bakanlı̆̆ Yayınlan, İstanbul 1990.

Cevdet Paşa, Tezakix, 13-20, haz. Cavid Baysun, Türk Tarih Kurumu Yayınlan, Ankara 1991. 
Çakan, İsmail-Muhammed Eroğlu, "Abdullah b. Abbas", Tïrkiye Diyanet Vakfi İslam Ansiklopedisi, I(1988), s. 76-78.

Çeşmeli, İbrahim, "Sogdlularda Cenaze Töreni ve Cennete Yükseliş Sahneleri”, Mimarlkk ve Dekorasyon, 178 (2008), s. 88-94.

Çoruhlu, Yaşar, "Kurgan ve Çadır (Yurt)'dan Kümbet ve Türbeye Geçiş", Geşmişten Günümüze Mezarlk Kültürü ve İnsan Hayatına Etkileri Sempozyumu, 18-20 Arahk 1998, AKSM-İstanbul, İstanbul 1999, s. 47-63.

Danesvari, Abbas, Medieval Tomb Towers of Iran an Iconographical Study, Mazdâ Publishers, Lexington, 1986.

Diyarbekirli Nejat, Türklerde Mezar Yapısı ve Defin Merasimleri”, Türk Külttürü Araştırmalan, Prof. Dr. Muharrem Ergin'e Armağan, 28/1-2(1992), s. 53-62.

D’Ohsson, I. M., Haremi-i Humâyân, çev. Ayla Düz, İstanbul 1972.

Eldem, Edhem, İstanbul'da Ölüm: Osmanl İslam Külttüründe Ölüm ve Ritüelleri, Osmanlı Bankası Arşive ve Araşturma Merkezi, İstanbul 2005.

Emecen, Feridun, “Osman II”, Türkiye Diyanet Vakfi Islam Ansiklopedisi, 33 (2007), s. 453-456.

Ertuğ, Zeynep Tarım, XVI. Yüzynl Osmanl Devleti'nde Cültus ve Cenaze Törenleri, Kültür Bakanlı̆ı Yayınları, Ankara 1999.

Evliya Çelebi b. Derviş Mehemmed Zilli, Evliya Çelebi Seyahatnamesi Topkapı Sarayn Kütüphanesi Revan 1457 Numaralı Yazmamen Transkripsiyonu-Dizini, haz. Seyit Ali Kahraman-Yücel Dağh, Yapı Kredi Yayınlan, İstanbul 2002.

Eyice, Semavi, "Hudâvendigar Meşhedi", Türkiye Diyanet Vakfi İslam Ansiklopedisi, 18(1998), s. 295-296.

—_, "Mustafa 1-Sultan İbrâhim Türbesi", Dïnden Bugüne İstanbul Ansiklopedisi, 5 (1994), s. 543-545.

Fatih Devri Kaynaklanndan Düstûrnâme-i Enveri, Osmanl Tarihi Kismı (1299-1456), haz. Necdet Öztürk, Kitabevi Yaymlan, İstanbul 2003.

Findıklıı Silâhdar Mehmed Ağa, Silâhdar Tarihi, c. II, İstanbul 1928.

—, Nusretnâme, c. I-II, sad. İsmet Parmaksızoğlu, İstanbul 1962.

Görkem, İsmail, "Türk Dünyasında Yas Törenleri ve Ağttlar", Türk Dünyası Araştırmalan, 77(1992), s. 158-166.

Hasan Bey-zâde Ahmed Paşa, Hasan Bey-zâde Tarihi, c. III, haz. Şevki Nezihi Aykut, Türk Tarih Kurumu Yayınlan, Ankara, 2004.

İbni Tagnberdi, En-Nucûm'uz-Zâhire (Parldayan Yulduzlar), çev. D. Ahsen Batur, Selenge Yayınlan, İstanbul 2013.

İnalcık, Halil, “Orhan”, Türkiye Diyanet Vakfi Íslam Ansiklopedisi, 33(2007), s. 375-386.

-, "Osman I", Türkiye Diyanet Vakfi Íslam Ansiklopedisi, 33(2007), s. 443-453. 
İnan, Abdülkadir, Tarihte ve Bugün Şamanizm Materyaller ve Araşttrmalar, Türk Tarih Kurumu Yayunları, Ankara 1954.

Jordanes, Romana et Getica. Monumenta Germaniae Historica: Auctores Antiquissimi, Ed. Theodor Mommsen, Berlin 1882.

Kandemir, M. Yaşar, "Ahmed b. Hanbel", Türkiye Diyanet Vakfi Íslam Ansiklopedisi, 2(1989), s. 75-80. ", "Ebû Hüreyre", Türkiye Diyanet Vakfi İslam Ansiklopedisi, 10(1994), s. 160-167.

Karaman, Hayreddin, “Ölüm, Ölü, Defin ve Merasimler”, Cimetières et Traditions Funéraires dans le Monde Islamique İslâm Dünyasinda Mezarlklar ve Defin Gelenekleri, c. I, ed. Jean-Louis BacquéAksel Tibet, Türk Tarih Kurumu Yayınları, Ankara 1996, s. 3-15.

Köprülü, Fuat, Edebiyat Araştrrmalan, Türk Tarih Kurumu Yaynlanı, Ankara 1986.

Kuban, Doğan, "Sultan Selim Külliyesi", Dünden Bugüne İstanbul Ansiklopedisi, 7(1994), s. 62-63.

Küçük, Cevdet, "Murad V", Türkiye Diyanet Vakfi Islam Ansiklopedisi, 31(2006), s. 183-185.

Kütükoğlu, Bekir, "Süleyman II", İslam Ansiklopedisi, 11(1993), s. 155-170.

Mangho-un Niuça Tobça'an (Yüan-Ch'ao Pi-shi), Moğollarn Gizli Tarihi, çev. Ahmet Temir, Türk Tarih Kurumu Yayınlan, Ankara 1995.

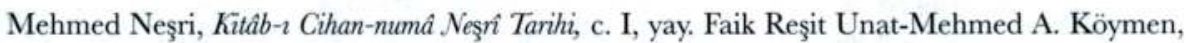
Türk Tarih Kurumu Yayınları, Ankara 1987.

Moltke, Helmuth von, Moltke'nin Tïrkiye Mektuplan, çev. Hayrullah Örs, Remzi Kitabevi, İstanbul, 1969.

Müneccimbaşı Ahmed b. Lütfullah, Camiü'd-Düvel Osmanl Tarihi (1299-1481), yay. Ahmet Ağ1rakça, İnsan Yayınları, İstanbul 1995.

Naîmâ, Mustafa Efendi, Târih-iNa 'îmâ (Ravizatü'l-Hüseyin Fì Hulâsati Ahbâri'l-Hâfikayn), c. II, haz. Mehmet İpşirli, Türk Tarih Kurumu Yayınları, Ankara 2007.

Önkal, Hakkı, Osmanl Hanedan Türbeleri, Kültür Bakanlığı Yayınları, Ankara 1992.

Örnek, Sedat Veyis, Anadolu Folklorunda Ölüm, Ankara Universitesi Dil ve Tarih-Coğrafya Fakültesi Yayınları, Ankara 1979.

Özcan, Abdülkadir, "Mahmud I", Türkiye Diyanet Vakfi İslam Ansiklopedisi, 27(2003), s. 348-352.

—_, "Mahmed IV", Tiürkiye Diyanet Vakfi Íslam Ansiklopedisi, 28(2003), s. 414-418.

__, "Mustafa II", Türkiye Diyanet Vakfi İslam Ansiklopedisi, 31(2006), s. 275-280.

Özel, Ahmet, "Ali el-Kâri", Türkiye Diyanet Vakfi İslam Ansiklopedisi, 2(1989), s. 403-405.

Pakalın, Mehmet Zeki, Osmanh Tarih Değimleri ve Terimleri Sözlüğü, c. I-III, Milli Eğitim Bakanlığı Yayınlarn, İstanbul 1993.

Perin, Hélène, "Kazaklarda ve Kırgızlarda Kara Ui Yurdu ve Yas Tutma (Çağdaş Etnografya Verilerine Göre)”, Osmanhlar ve Ölüm, yay. haz. G. Veinstein, çev. Ela Gültekin, İletişim Yayınlan, İstanbul 2007, s. 75-92. 
Piyadeoğlu, Cihan, "Büyük Selçuklular Dünyasında Yas Tutma Âdetleri ve Taziye Merasimleri” Trakya Universitesi Edebiyat Fakültesi Dergisi, 2/3(2012), s. 29-41.

Raghep, Youssef, "İslam Hukukuna Göre Mezarnn Yapısı", Cimetières et Traditions Funéraires dans le Monde Islamique Islatm Dünyasnda Mezarlkklar ve Defin Gelenekleri, c. I, ed. Jean-Louis BacquéAksel Tibet, Türk Tarih Kurumu Yaynlan, Ankara 1996, s. 17-23.

Rosedale, H. G., Queen Elizabeth and the Levant Company: A Diplomatic and Literary Episode of the Establishment of Our Trade with Turkey, Oxford University Press, London 1904.

Roux, Jean-Paul, Altay Türklerinde Olüm, çev. Aykut Kazancıgil, Kabalcı Yayınevi, İstanbul 1999. Sahîh-i Buhari ve Tercemesi, c. 3, müt. Mehmed Sofuoğlu, Ötüken Yaynları, İstanbul 1987.

Sakaoğlu, Necdet, “Abdülaziz”, Dünden Bugüne İstanbul Ansiklopedisi, 1(1993), s. 22-26. , "Mehmed VI (Vahideddin)", Dünden Bugüne İstanbul Ansiklopedisi, 5(1994), s. 349-354.

Sancaoğlu, Fikret, "Osman III", Türkiye Diyanet Vakfi İslam Ansiklopedisi, 33(2007), s. 456-459.

Schimmel, Annemarie, Sayılarn Gizemi, çev. Mustafa Küpüşoğlu, Kabalcı Yayınlan, İstanbul 2000.

Selaniki Mustafa Efendi, Tarih-i Selânikî, haz. Mehmet İpşirli, İstanbul Úniversitesi Yayınları, İstanbul 1989.

Seyid, Lokman, Hünernâme, Cild-i sâni, İstanbul 1589, Topkapı Sarayı Müzesi Kütüphanesi, H. 1524.

Solak-zâde Mehmed Hemdemî Çelebî, Solak-zâde Tarihi, Mahmud Bey Matbaası, İstanbul 1297 (1880).

Stephan, Gerlach, Türkiye Günlüğü 1573-1576, c. I, ed. Kemal Beydilli, çev. Türkis Noyan, Kitap Yayınevi, Istanbul, 2007.

Şehsuvaroglu, Haluk Y., Sultan Aziz; Hususî, Siyasî Hayat, Devri ve Ölümü, Hilmi Kitabevi, İstanbul 1949.

Taşağl, Ahmet, Göktürkler, Türk Tarih Kurumu Yayınlan, Ankara 1995.

Tekinalp, V. Macit, "Remodelling The Monastery of Hagios Ioannes in Prousa Ad Olympum (Modern Bursa, Türkiye)" Trudy Gosudarstvennogo Ermitaja-The State Hermitage Papers, 53 (2010), s. 62-177.

Tekindağ, Şahabeddin, "Bayezid'in Ölümü Meselesi”, Tarih Dergisi, 24(1970), s. 1-16.

—_, "Padişahlar İçin Tertiplenen Türk Usulü Cenaze”, Türk Kültürü, 17(1963), s. 46-47.

Tryjarski, Edward, Türkler ve Ölüm, çev. Hafize Er, Pinhan Yayınlan, İstanbul 2012.

Uzunçarşılı, İsmail Hakkı, Osmanl Devletinin Saray Teşkilatı, Türk Tarih Kurumu Yayınları, Ankara 1984.

Vatin, Nicolas-Veinstein, Gilles, "Les obsèques des sultans ottomans de Mehmed II à Ahmed I "(1481-1616)", Les Ottomans et la mort: permanences et mutations, ed. Gilles Veinstein, E. J. Brill, Leiden, New York, Köln 1996, s. 207-244. 
"II. Mehmed'in Ölümü (1481)", Osmanllar ve Ölüm, yay. haz. Gilles Veinstein, çev. Ela Gültekin, İstanbul 2007, s. 227-251.

, II. Mehmed'den I. Ahmed'e Osmanlı Padişahlarının Cenaze Törenleri (181-1616)", Osmanllar ve Ölüm, yay. haz. Gilles Veinstein, çev. Ela Gültekin, İletişim Yayınlan, İstanbul 2007, s. 253-298.

- Le Sérail ébranlé Essai sur les morts, dépositions et avènements des sultans ottomans (XIV-XIX siècle), Fayard, Paris 2003.

Yanatma, Servet, "The Deaths and Funeral Ceremonies of Ottoman Sultans (From Sultan Mahmud II to Sultan Vahideddin)”, Boğaziçi Úniversitesi, Sosyal Bilimler Lisansüstü Araşturmaları Enstitüsü, Yayımlanmamış Yüksel Lisana Tezi, İstanbul 2006.

Yazar, Turgay, "Çadır-Bark-Türbe”, Geşmişten Günümüze Mezarlık Kültü̈rü ve Insan Hayatına Etkileri Sempozyumu, 18-20 Aralık 1998, AKSM-İstanbul, İstanbul 1999, s. 418-431.

Yulmazer, Ziya, "Murad IV", Türkiye Diyanet Vakfi İslam Ansiklopedisi, 31(2006), s. 177-182.

Zeynü'd-dîn Ahmed b. Ahmed b. Abdi'l-Lâtifi'z-Zebîhî, Sahîh-i Buhari Muhtasan Tecrid-i Sarîh Tercemesi ve Şerhi, cilt 4, müt. ve şar. Kâmil Miras, Diyanet İşleri Başkanlığı Yayınlan, Ankara 1980.

\section{E - KAYNAKÇA}

Mehmed Es'ad Mehdî, Sadaret Teşrnfât Defteri, haz. Úzeyir Yıldırım, ed. Abdülkadir Özcan, Kültür ve Turizm Bakanlığı Yayınlan, İstanbul 2007. http://ekitap.kulturturizm.gov.tr/belge/1-83610/mehmed-esad-medhi---sadaret-tesrifat defteri.html

Kur'an-1 Kerim ve Türkçe Meâli (Diyanet İşleri Başkanlı̆̆ı)

http://www.diyanet.gov.tr/kuran/default.asp?mnct $=36$ 